\title{
Trials and Tribulations in the Frontline Treatment of Older Adults with Acute Myeloid Leukemia
}

\author{
Adam S. Zayac ${ }^{1}$ (D) and John L. Reagan $2, *(\mathbb{D})$ \\ 1 Warren Alpert Medical School of Brown University, Providence, RI 02903, USA; adam_zayac@brown.edu \\ 2 Division of Hematology-Oncology, Rhode Island Hospital, Providence, RI 02903, USA \\ * Correspondence: john_reagan@brown.edu; Tel.: +1-401-444-5342; Fax: +1-401-444-9375
}

check for updates

Citation: Zayac, A.S.; Reagan, J.L. Trials and Tribulations in the Frontline Treatment of Older Adults with Acute Myeloid Leukemia. Hemato 2021, 2, 515-544. https:// doi.org/10.3390/hemato2030033

Academic Editors: Ugo Testa and Roland B. Walter

Received: 1 July 2021

Accepted: 13 August 2021

Published: 18 August 2021

Publisher's Note: MDPI stays neutral with regard to jurisdictional claims in published maps and institutional affiliations.

Copyright: (c) 2021 by the authors. Licensee MDPI, Basel, Switzerland. This article is an open access article distributed under the terms and conditions of the Creative Commons Attribution (CC BY) license (https:/ / creativecommons.org/licenses/by/ $4.0 /)$.

\begin{abstract}
Acute myeloid leukemia (AML) is a heterogeneous aggressive hematologic malignancy derived from malignant clones that promote their own growth and survival at the expense of normal hematopoiesis resulting in life-threatening bleeding and infections. Traditional initial AML therapy has been centered on a backbone of intensive chemotherapy often composed of an anthracycline and cytarabine. This strategy has proven most effective in patients less than 60 years of age due to both patient-related tolerability factors as well as changes in AML biology centered on chemotherapy refractory mutational profiles that are seen with advancing age. Recent improvements in frontline AML therapy have been seen in patients 60 years of age and over, a population most typically referred to as "older" adult AML. Herein, we describe the characteristics of "older" adult AML, review the differences in outcomes amongst those 60-75 and those over 75 years of age, and cite challenges in delivering frontline therapies within this group based not only on therapeutic toxicity but also on the patient's overall level of "fitness" and inherent biology. We also discuss the role of targeted therapies that inhibit specific mutations and have the potential to deliver improved efficacy with less side effects while also recognizing that some selected older AML patients still benefit from intensive induction therapy.
\end{abstract}

Keywords: acute myeloid leukemia; older adult; frontline treatment

\section{Introduction}

Acute myeloid leukemia (AML) is an aggressive hematologic malignancy affecting about $0.5 \%$ of people in their lifetime. Over the last few decades, a growing understanding of AML has revealed it to be a heterogenous disease with a widely variable prognosis. This is largely driven by disease biology, the ability to tolerate highly toxic multi-agent chemotherapy and, in most cases, undergo allogeneic stem cell transplantation to be cured of disease. In the best of circumstances, this is a tenuous situation with life-altering implications. Our review will focus on the characteristics of AML in "older" patients and discuss frontline management approaches for this population that can range in terms of performance status from "fit" to medically "frail". We also discuss future directions for treatment in this disproportionately afflicted, vulnerable population.

\section{AML in "Older" Adults}

While induction chemotherapy with a combination of an anthracycline and antimetabolite has served as the backbone for the curative treatment of AML, this is highly toxic and may not be feasible to give to all patients. Furthermore, with the median age at AML diagnosis of 68 years old and the highest rates of AML in individuals in their eighth and ninth decades of life, there are often several competing factors altering prognosis and treatment compared with their younger counterparts. These include both patient and disease factors. The definition of "older" varies by study and guidelines [1,2]. For the purposes of this review, we will focus on the treatment of patients age 60 and older with non-promyelocytic acute myeloid leukemia. 


\subsection{Biology of Disease}

AML is a highly heterogeneous disease, with a range of understanding regarding the molecular and cytogenetic factors affecting prognosis and treatment. Older patients have numerous features that contribute to worse outcomes compared with in younger patients. High rates of primitive (CD34+) leukemic blasts, antecedent hematologic disorders, and trilineage dysplasia are present $[3,4]$. Furthermore, high rates of multidrug resistance-1 (MDR-1) expression leading to increased potential for chemotherapy extrusion are common $[3,4]$.

In the SWOG-9031 trial, $71 \%$ of the elderly patients (age 55 and older) expressed MDR- 1 , and $25 \%$ of patients had adverse cytogenetics, while only $4 \%$ had favorable cytogenetics [5]. Suarez et al. later found higher expression of the multidrug resistance (MDR) protein, P-gp, and lower expression of the anti-apoptotic protein, APO2.7, in CD34+ leukemic blasts amongst elderly patients. However, the expression of P-gp was not statistically different between younger and older patients with CD34+ blasts [4]. These findings raise concern regarding the inherent resistance of leukemic stem cells to cytotoxic chemotherapy, rendering intensive treatment approaches less effective.

In older adults, monosomal karyotypes, -5 and -7 , as well as other adverse cytogenetic abnormalities, including $17 \mathrm{p}, 11 \mathrm{q},+8$, and complex karyotypes predominate, while favorable cytogenetic abnormalities are uncommon [3]. In a cytogenetic analysis of CALGB-8461 that compromised patients over 60 years with predominantly de novo AML $(97.5 \%)$, a complex karyotype with $\geq 3$ abnormalities (19\% of patients) and "rare aberrations" ( $5 \%$ of patients) were associated with lower complete remission (CR) rates, while complex karyotype with $\geq 5$ abnormalities ( $15 \%$ of patients) and "rare aberrations" were also associated with inferior disease-free survival (DFS) and overall survival (OS) [6].

Another cytogenetic analysis of AML patients over 60 years old treated with induction chemotherapy in the HD98-B protocol showed adverse cytogenetics present in $35 \%$ of enrolled patients and once again was associated with an inferior OS (HR 2.24; 95\% CI: 1.74-2.88). Favorable cytogenetics were associated with a median OS of 26.4 months compared with just 5.1 months for patients with adverse disease. Patients over the age of 70 years old with adverse cytogenetic features fared even more dismally, with a median OS of 3.1 months compared to 6.3 months for those over 70 years old without adverse features [7]. A more recent German study of patients age 75 years or older treated intensively for AML found TET2 (42\%), DMNT3A (35\%), NPM1 (32\%), SRSF2 (25\%), and ASXL1 (21\%) to be the most common mutations and, once more, corroborated that adverse cytogenetics by the UK Medical Research Council (MRC) classification were associated with poorer OS.

Furthermore, IDH1 mutations had poor complete response (CR) rates and survival [8], which has been corroborated by additional studies even when NPM1 is present [9]. When examined in and of themselves, NPM1 mutations appear to still confer a favorable prognosis in older adults treated with intensive chemotherapy $[10,11]$ although the data re conflicting [12]. Genetic risk classification based on European LeukemiaNet remains the most widely used risk stratification system for both "young" and "older" adults with AML. Notably, patients with ASXL1 and $p 53$ mutations, which are prevalent in older adults, are at adverse risk while NPM1 mutations without a high allelic ration FLT-ITD mutation are favorable [13].

\subsubsection{Secondary AML}

Antecedent hematologic disorders, like myelodysplastic syndrome (MDS) and myeloproliferative neoplasms (MPNs), can eventually lead to secondary AML (sAML). MDS and MPNs are cancers that are secondary to clonal aberrations in myeloid development, while sAML usually develops through clonal evolution with a different subclone emerging during the disease course that is apart from the initial dominant clone. The majority of sAML ( $60 \%$ of cases) evolves from MDS with the remainder evolving from MPNs, including chronic myelomonocytic leukemia. Secondary AML in total accounts for $20-25 \%$ of all AML cases and, as with de novo AML, has a median age of onset in the mid 60s, thereby, 
underscoring its preponderance in the older adult population $[14,15]$. The importance and characteristic findings of sAML are exemplified by the 2016 designation by the World Health Organization of AML developing from MDS as a distinct clinicopathologic entity termed "AML with myelodysplasia-related changes" (AML-MRC) [16].

Historically, a sAML diagnosis has been based solely on the blast count. Those patients with less than $20 \%$ blasts are given a diagnosis of MDS, while those patients with $20 \%$ or more blasts are said to have "transformed" to AML. This paradigm has been challenged as of late by evidence for specific genetic mutations present in the founding clone and subsequent daughter subclones in the progression of MDS to sAML that represent defined patterns that could identify progression to AML before the $20 \%$ myeloblast threshold is reached [17].

Furthermore, while there is a difference in the types of mutations and mutational variant allele frequencies (VAFs) between MDS and AML, this difference is no longer apparent when high-risk MDS is compared to AML, thereby, suggesting that high-risk MDS and AML represent a continuum of the same disease with the same response to therapy and similar prognoses [18]. Clonal evolution with the acquisition of additional mutations is also a hallmark of AML derived from MPNs and, like sAML from MDS, carries a poor prognosis [19].

The clonal evolution of sAML from an antecedent MDS often leads to a monosomal or complex karyotype while TP53, ASXL1, TET2, DNMT3A, IDH1/2, and NRAS / KRAS mutations are often seen in SAML with both prior MDS and MPNs [19,20]. Most importantly, those patients with sAML and antecedent MDS often have already been exposed to and progressed through hypomethylator therapy.

\subsubsection{Age}

Age in and of itself is a critical factor in the prognosis and treatment selection in AML. Diminished complete response rates and overall survival have been a hallmark of AML studies. The initial CALG studies that identified $7+3$ as the standard therapy for AML show a clear distinction the in the complete remission (CR) rates and increased risk of death with induction between those $<60$ and those 60 and older [21,22]. Worsening outcomes with advancing age has been seen in subsequent decades as well with $C R$ rates in the $70-80 \%$ range for patients $<40$-years-old, $60-70 \%$ for $40-60$-years-old; and $50-60 \%$ in those $>60$ [23-26].

A critical division regarding outcomes is even seen amongst the age 60 and over patient subgroup. The HD98-B trial included 361 patients over 60 years old treated with intensive chemotherapy and found that age over 70 was independently associated with inferior OS (HR 2.34; 95\% CI: 1.77-3.08) [7]. When further stratified by the presence of adverse cytogenetics, survival was best amongst patients under 70 years old without adverse changes (3-year OS: 26\%, median OS 17.5 mos) followed by patients under 70 years old with adverse features OR over 70 years old without adverse changes (3-year OS: 6\%; mOS 7.2 mos and 6.3 mos, respectively) and lastly patients over 70 years old with adverse cytogenetics (3-year OS: $2 \%$; mOS 3.1 mos) [7].

Despite these patients being able to tolerate intensive chemotherapy, most patients did not fare well given their age and/or cytogenetic features [7]. Interestingly, in regards to non-trial data, an analysis of the SEER database found improvements in the response rates (RR) and 12-month survival with each decade from 1977-2006 for patients who were 65-74 years old but no improvement for their 75 years of age and older counterparts despite the approval of agents to treat older patients within this timeframe [27]. This variation in survival underscores a need to discuss the prognosis and treatment of those between age 60 and 74 years old and patients 75 years old or more separately. Later in this review, we discuss the treatment of those between age 60 and 74 years old and patients 75 years old or more separately. 


\subsection{Comorbidities}

In addition to biological age, concomitant health conditions and their treatments may limit chemotherapeutic options and/or require dose reductions. One retrospective study found that patients over 60 years old had higher rates of diabetes and higher baseline Charleston Comorbidity indexes (CCI) than those younger than 60 years [24]. Additionally, higher mean blood glucose levels and greater blood glucose variability are associated with significantly lower remission rates and higher mortality rates in older patients [24]. Polypharmacy is another important aspect to keep in mind when caring for older AML patients. The use of four (4) or more medications is associated with lower CR rates, increased 30-day mortality, and overall mortality than one medication or less [28].

A tool to consider when assessing a patient's ability to tolerate induction chemotherapy is the hematopoietic cell transplant comorbidity index (HCT-CI). The HCT-CI was initially created to assess the risk of non-relapse mortality and survival before allogeneic stem cell transplantation. Hence, it is a risk score that incorporates a number of significant comorbidities. HCT-CI was also found to be predictive of overall survival and early death rates in elderly (60 years and older) AML patients with induction therapy [29].

\subsection{Geriatric Assessment}

Standardized performance status assessments, such as the Eastern Cooperative Oncology Group (ECOG) performance status or Karnofsky performance status (KPS), are the backbone of assessing a patient's ability to receive treatment. These assessments serve as the benchmark for assessing fitness for clinical trial enrollment. However, they are limited and can miss significant frailty and disability in the heterogenous and vulnerable elderly population. Comprehensive geriatric assessments (GA) evaluate comorbidities, nutritional status, polypharmacy, functional status, cognitive function, and test for geriatric syndromes (frailty, depression, anxiety, etc.).

While not initially created for the assessment of oncology patients, they have subsequently been found to predict mortality and chemotherapy-related adverse effects [30,31]. AML and its treatment is among the most intensive stressors that a person can experience. Often, it evolves rapidly and may even require lengthy hospitalization and intensive supportive care. Several studies have gone on to assess the role and feasibility of geriatric assessments in patients receiving induction chemotherapy and even stem cell transplantation for AML in order to accurately depict the effect of induction chemotherapy on older patients [32-38].

Klepin et al. initially reported the feasibility of a bedside geriatric assessment and noted its ability to uncover impairments beyond those captured by subjective performance status [32]. Impairments in cognition and objectively measured physical function, assessed by GA were associated with worse overall survival in older patients receiving induction chemotherapy for AML [33]. Furthermore, older patients with FLT3-mutated AML on clinical trial were found to have a decline in several domains of their GA, including their physical function, nutritional parameters, social activity, and mental health [36]. A decline in objective physical function and depression were also associated with worse OS during post-remission therapies [37].

In patients treated with "non-intensive" regimens, KPS $<80$, an elevated fatigue index, and a diminished activity of daily living (ADL) index were associated with worse overall survival, which was seen in patients treated with best supportive care only or hypomethylating agents [35]. Utilizing the information obtained from GAs and combining it with cytogenetic and molecular information to optimally tailor individual treatment within this heterogenous group is under study and likely represents a step forward in the treatment of AML in older adults [39].

\section{Initial Treatment}

AML is an aggressive, rapidly progressive, and fatal disease if left untreated. However, it can be responsive to curative and palliative chemotherapy treatments. While a variety of 
treatments have been studied, the first decision point remains an assessment of the patient's fitness. Historically, combination induction chemotherapy was the best option for attaining remission. However, as additional agents and combinations are studied, we have found that other "less" intensive options may also lead to remission. After an assessment of the patient fitness, treatment may be further guided by the cytogenetic and molecular variables specific to each person's disease [1]. Below, we discuss some of the frontline treatment options available. Careful assessment of the patient, their level of fitness, biologic aspects of their leukemia, and their social support structures is needed prior to therapy selection.

\section{1. "Fit" Induction Therapy}

The standard treatment approach for patients who are deemed "fit" for intensive treatment remains a backbone of an anthracycline and cytarabine ('7+3') in a variety of formulations and dosages and in combination with other drugs. The ideal dose and choice of anthracycline is not entirely clear. A phase 3 study by ECOG (Table 1) showed no difference in the response rates or survival between daunorubicin $45 \mathrm{mg} / \mathrm{m}^{2}$ on days $1-3$, mitoxantrone $12 \mathrm{mg} / \mathrm{m}^{2}$ on days $1-3$ or idarubicin $12 \mathrm{mg} / \mathrm{m}^{2}$ on days $1-3$ when combined with cytarabine $100 \mathrm{mg} / \mathrm{m}^{2}$ continuous on days 1-7 [40]. Another phase 3 study by Ohtake et al. comparing daunorubicin $50 \mathrm{mg} / \mathrm{m}^{2}$ with idarubicin $12 \mathrm{mg} / \mathrm{m}^{2}$, showed similar outcomes [41].

Lowenberg et al. reported on a phase 3 study of patients age 60 years and older who were randomized to daunorubicin $45 \mathrm{mg} / \mathrm{m}^{2}$ on days $1-3$ or daunorubicin $90 \mathrm{mg} / \mathrm{m}^{2}$ on days 1-3 [25]. Both groups received this with a seven-day continuous infusion of cytarabine $200 \mathrm{mg} / \mathrm{m}^{2}$ and later received cytarabine $1000 \mathrm{mg} / \mathrm{m}^{2}$ every $12 \mathrm{~h}$ for 6 days following their induction cycle [25]. The overall cohort had significantly higher CR rates after both the first cycle $(52 \%$ vs. $35 \%, p<0.001)$ and second cycle $(64 \%$ vs. $54 \%, p=0.002)$ without higher rates of hematologic toxicities, 30-day mortality, or moderate-life threatening adverse effects [25].

This failed to result in an improvement in the event-free survival (EFS) or OS. However, in patients between 60-65 years old, escalated-dose daunorubicin resulted in higher CR rates $(73 \%$ vs. $51 \%, 0.02)$, EFS $(29 \%$ vs. $14 \%, p=0.02)$, and OS $(38 \%$ vs. $23 \%, p=0.007)$ compared to standard-dose daunorubicin [25]. Additionally, there was no difference in CR or EFS between these two dose levels in core-binding factor (CBF) leukemias. 
Table 1. Intensive induction regimens for AML with an emphasis on older adult outcomes.

\begin{tabular}{|c|c|c|c|c|c|c|}
\hline Study/Author & Phase/Population & Median Age (Years) [Range] & Study Medication & CR & DFS/EFS/PFS/RFS & OS \\
\hline \multicolumn{7}{|c|}{ Anthracycline + Cytarabine-Based Regimens } \\
\hline $\begin{array}{c}\text { ECOG E3993; Rowe et al. } \\
\text { [40] }\end{array}$ & $\begin{array}{c}\text { III, } 348 \text { patients ( } \geq 55 \text { years old) with } \\
\text { newly diagnosed AML fit to receive } 7+3 \\
\text { induction chemotherapy }\end{array}$ & $\begin{array}{l}\text { Daunorubicin } \\
67(56-82) \\
\text { Mitoxantrone } \\
69(56-84) \\
\\
\text { Idarubicin } \\
67.5(56-86)\end{array}$ & $\begin{array}{c}\text { Daunorubicin } 45 \mathrm{mg} / \mathrm{m}^{2} \text { vs. } \\
\text { Mitoxantrone } 12 \mathrm{mg} / \mathrm{m}^{2} \text { vs. } \\
\text { Idarubicin } 12 \mathrm{mg} / \mathrm{m}^{2} . \text { All on } \\
\text { days } 1-3 \\
\text { All received cytarabine } 100 \\
\mathrm{mg} / \mathrm{m}^{2} \text { cont. on days } 1-7 .\end{array}$ & $\begin{array}{c}\text { All: CR } 42 \% \\
\text { Daunorubicin } \\
\text { CR } 40 \% \\
\text { Mitoxantrone } \\
\text { CR } 46 \% \\
\text { Idarubicin } \\
\text { CR } 43 \%\end{array}$ & $\begin{array}{c}\text { All: } \\
\text { Median DFS } 7 \mathrm{mo} \\
\text { Daunorubicin } \\
\text { Median DFS } 5.7 \mathrm{mo} \\
\text { Mitoxantrone } \\
\text { Median DFS } 7.1 \mathrm{mo} \\
\text { Idarubicin } \\
\text { Median DFS } 9.4 \mathrm{mo}\end{array}$ & $\begin{array}{l}\text { All: mOS } 7.5 \mathrm{mo} \\
\text { Daunorubicin } \\
\text { mOS } 7.7 \text { mo } \\
\text { Mitoxantrone } \\
\text { mOS } 7.5 \mathrm{mo} \\
\text { Idarubicin } \\
\text { mOS } 7.2 \mathrm{mo}\end{array}$ \\
\hline $\begin{array}{l}\text { JALSG AML201; Ohtake } \\
\text { et al. [41] }\end{array}$ & $\begin{array}{l}\text { III, } 1057 \text { patients (age } 15-64 \text { years old) } \\
\text { with de novo AML fit to receive } 7+3 \\
\text { induction chemotherapy }\end{array}$ & $\begin{array}{l}\text { All: } 47 \text { (15-64) } \\
\text { Daunorubicin } \\
47 \text { (15-64) } \\
\text { Idarubicin } \\
47 \text { (15-64) }\end{array}$ & $\begin{array}{l}\text { Daunorubicin } 50 \mathrm{mg} / \mathrm{m}^{2} \text { days } \\
1-5 \mathrm{vs} . \\
\text { Idarubicin } 12 \mathrm{mg} / \mathrm{m}^{2} \text { days } 1-3 . \\
\text { All received cytarabine } 100 \\
\mathrm{mg} / \mathrm{m}^{2} \text { cont. on days } 1-7 .\end{array}$ & $\begin{array}{l}\text { All: CR } 77.9 \% \\
\text { Daunorubicin } \\
\text { CR } 77.5 \% \\
\text { Idarubicin } \\
\text { CR } 78.2 \% \\
\end{array}$ & $\begin{array}{c}\text { Daunorubicin } \\
\text { 5-yr predicted RFS 41\% } \\
\text { Idarubicin5-yr predicted RFS } \\
41 \%\end{array}$ & $\begin{array}{l}\text { Daunorubicin5-yr predicted } \\
\text { OS } 48 \% \\
\text { Idarubicin } \\
5 \text {-yr predicted OS } 48 \%\end{array}$ \\
\hline $\begin{array}{l}\text { HOVON-43-AMLSAKK } \\
\text { 30/01; Lowenberg et al. } \\
\text { [25] }\end{array}$ & $\begin{array}{l}\text { III, } 813 \text { patients ( } \geq 60 \text { years old) with } \\
\text { newly diagnosed AML or RAEB with } \\
\text { IPS of } 1.5 \text { or greater fit to receive } 7+3 \\
\text { induction chemotherapy }\end{array}$ & $\begin{array}{c}67(60-84) \\
26 \%>70 \text { years }\end{array}$ & $\begin{array}{c}\text { Daunorubicin } \\
45 \mathrm{mg} / \mathrm{m}^{2} \mathrm{vs} .90 \mathrm{mg} / \mathrm{m}^{2} \text { on } \\
\text { days } 1-3 . \text { All received } \\
\text { cytarabine } 200 \mathrm{mg} / \mathrm{m}^{2} \text { cont. on } \\
\text { days } 1-7 .\end{array}$ & $\begin{array}{c}\text { 1st cycle CR } 35 \% \text { vs. } 52 \% \\
(p<0.001) \\
\\
\text { After consolidation CR } \\
54 \% \text { vs. } 64 \% \\
\text { OR } 1.59[1.18-2.15] \\
(p=0.002) \\
60-65 \text { yr old CR51\% vs. } \\
73 \% \\
\text { OR 2.64 [1.63-4.29] }(p= \\
0.02)\end{array}$ & $\begin{array}{c}\text { All EFS } \\
17 \% \text { vs. } 20 \%(p=0.12) \\
\\
\text { 60-65 yr old EFS } \\
14 \% \text { vs. } 29 \% \\
\text { OR } 0.68[0.53-0.87] \\
(p=0.02) \\
\text { All DFS } \\
29 \% \text { vs. } 30 \%(p=0.77) \\
\text { 60-65 yr old DFS } \\
27 \% \text { vs. } 39 \%(p=0.43)\end{array}$ & 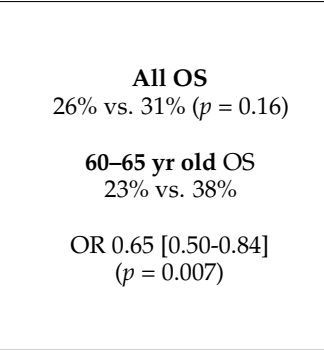 \\
\hline $\begin{array}{l}\text { NCRI-AML17; Burnett } \\
\text { et al. [42] }\end{array}$ & $\begin{array}{l}\text { III, } 1206 \text { patients ( } \geq 16 \text { years old) with } \\
\text { newly diagnosed AML or high-risk MDS } \\
\text { ( }>10 \% \text { blasts) fit to receive } 7+3 \\
\text { induction chemotherapy }\end{array}$ & $\begin{array}{c}53(16-72) \\
26 \% \geq 60 \text { years }\end{array}$ & $\begin{array}{c}\text { Daunorubicin: } \\
60 \mathrm{mg} / \mathrm{m}^{2} \mathrm{vs} .90 \mathrm{mg} / \mathrm{m}^{2} \text { on } \\
\text { days } 1-3 \text {. } \\
\text { All patients received cytarabine } \\
100 \mathrm{mg} / \mathrm{m}^{2} \mathrm{q} 12 \mathrm{~h} \text { on days } 1-10 . \\
\text { All patients received a second } \\
\text { induction containing } \\
\text { daunorubicin } 50 \mathrm{mg} / \mathrm{m}^{2} \text { except } \\
\text { subset of adverse-risk pts who } \\
\text { received FLAG-IDA. }\end{array}$ & $\begin{array}{c}\text { CR + CRi } 82 \% \\
84 \% \text { vs. } 81 \%(p=0.2) \\
1 \text { st cycle } \mathbf{C R}+\mathbf{C R i} 66 \% \text { vs. } \\
68 \%(p=0.4) \\
\text { CR } \\
75 \% \text { vs. } 73 \%(p=0.6)\end{array}$ & $\begin{array}{c}\text { 2-yr RFS } \\
48 \% \text { vs. } 51 \%(p=0.7)\end{array}$ & $\begin{array}{c}2 \text {-yr OS } \\
60 \% \text { vs. } 59 \%(p=0.15)\end{array}$ \\
\hline $\begin{array}{l}\text { NCT01145846; Lee et al. } \\
\text { [43] }\end{array}$ & $\begin{array}{l}\text { III, } 209 \text { patients ( } 15-65 \text { years old) with } \\
\text { newly diagnosed AML fit to receive } 7+3 \\
\text { induction chemotherapy }\end{array}$ & $\begin{array}{c}\text { Overall } \\
49 \text { (15-65) } \\
\text { Daunorubicin } 48.5 \\
\text { (15-65) } \\
\text { Idarubicin } \\
49(15-65)\end{array}$ & $\begin{array}{l}\text { Daunorubicin } 90 \mathrm{mg} / \mathrm{m} 2 \text { vs. } \\
\text { Idarubicin } 12 \mathrm{mg} / \mathrm{m} 2 \text { All on } \\
\text { days } 1-3 \text {. } \\
\text { All received cytarabine } 200 \\
\mathrm{mg} / \mathrm{m}^{2} \text { cont. on days } 1-7 .\end{array}$ & $\begin{array}{c}\text { OverallCR } \\
\text { Total } 77.6 \% \\
74.7 \% \text { vs. } 80.5 \%(p=0.224) \\
\text { CR after 1 } \\
\text { induction course } \\
\text { Total } 69.2 \% \\
66.7 \% \text { vs. } 71.1 \%(p=0.403)\end{array}$ & $\begin{array}{c}4-\mathrm{yr} \text { EFS } 48.2 \% \\
50.8 \% \text { vs. } 45.5 \%(p=0.772)\end{array}$ & $\begin{array}{c}4-\mathrm{yr} \text { OS } 52.8 \% \\
54.7 \% \text { vs. } 51.1 \%(p=0.756)\end{array}$ \\
\hline
\end{tabular}


Table 1. Cont

\begin{tabular}{|c|c|c|c|c|c|c|}
\hline Study/Author & Phase/Population & Median Age (Years) [Range] & Study Medication & CR & DFS/EFS/PFS/RFS & os \\
\hline $\begin{array}{l}\text { ALFA-9801; Pautas et al. } \\
\text { [44] }\end{array}$ & $\begin{array}{l}\text { III, } 468 \text { adult patients ( } 50-70 \text { years old) } \\
\text { with newly diagnosed AML (no prior } \\
\text { MPN or MDS) fit to receive } 7+3 \\
\text { induction chemotherapy }\end{array}$ & $\begin{array}{c}\text { Overall } \\
60(\mathrm{NR}) \\
\text { Idarubicin } 3 \mathrm{~d} \\
59.8(\mathrm{NR}) \\
\text { Idarubicin } 4 \mathrm{~d} \\
60(\mathrm{NR}) \\
\text { Daunorubicin } 59.7 \text { (NR) }\end{array}$ & $\begin{array}{c}\text { Idarubicin } \\
12 \mathrm{mg} / \mathrm{m}^{2} \text { on days } 1-3 \mathrm{vs} \text {. } \\
12 \mathrm{mg} / \mathrm{m}^{2} \text { on days } 1-4 \mathrm{vs} \text {. } \\
\text { Daunorubicin } 80 \mathrm{mg} / \mathrm{m}^{2} \text { on } \\
\text { days } 1-3 . \\
\text { All received cytarabine } 200 \\
\mathrm{mg} / \mathrm{m}^{2} \text { cont. on days } 1-7 .\end{array}$ & $\begin{array}{c}\text { CR } \\
\text { All 77\% } \\
83 \% \text { vs. } 78 \% \text { vs. } 70 \% \\
\text { OR } 1.75 \\
(p=0.04) \\
p=0.007 \text { for Idarubicin 3d } \\
\text { vs. Daunorubicin }\end{array}$ & $\begin{array}{c}\text { 2-yr EFS } 23.5 \% \\
\text { 4-yr EFS } 18 \% \\
\text { EFS did not differ between } 3 \\
\text { arms }(p=0.19)\end{array}$ & $\begin{array}{c}\text { Median OS } \\
17 \text { mo } \\
\text { 2-yr OS } 38 \% \\
\text { 4-yr OS } 26.5 \% \\
\text { OS did not differ between } 3 \\
\text { arms }(p=0.19)\end{array}$ \\
\hline $\begin{array}{l}\text { ALFA-0701; Castaigne } \\
\text { et al. [45] }\end{array}$ & $\begin{array}{l}\text { III, } 278 \text { adult patients ( } 50-70 \text { years old) } \\
\text { with de novo AML fit to receive } 7+3 \\
\text { induction chemotherapy }\end{array}$ & $\begin{array}{c}62.2(58.5-66.3) \\
\text { Gemtuzumab } \\
62.8(59.3-66.8) \\
\text { Control } \\
61.7(57.4-65.6)\end{array}$ & $\begin{array}{l}\text { Gemtuzumab ozogamicin } 3 \\
\mathrm{mg} / \mathrm{m}^{2}[\mathrm{max} 5 \mathrm{mg} \text { days } 1,4,7 \\
\text { for study arm. } \\
\\
\text { All received daunorubicin } 60 \\
\mathrm{mg} / \mathrm{m}^{2} \text { on days } 1-3 \text { and } \\
\text { cytarabine } 200 \mathrm{mg} / \mathrm{m}^{2} \text { cont. on } \\
\text { days } 1-7 .\end{array}$ & $\begin{array}{c}\text { CR + CRp } \\
81 \% \text { vs. } 75 \% \\
(p=0.25) \\
\text { CR } 73 \% \text { vs. } 72 \%\end{array}$ & 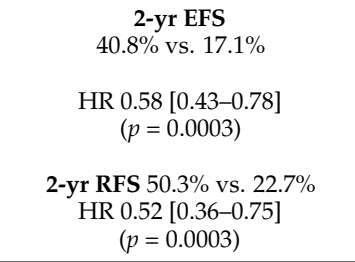 & $\begin{array}{c}\text { 2-yr OS } 53.2 \% \text { vs. } 41.9 \% \\
\text { HR } 0.69[0.49-0.98] \\
\quad(p=0.0368)\end{array}$ \\
\hline Hills et al. [46] & $\begin{array}{l}\text { Meta-analysis, } 3325 \text { patients ( } \geq 15 \text { years } \\
\text { old) with newly diagnosed AML or } \\
\text { high-risk MDS who were enrolled in } \\
\text { randomized clinical trials }\end{array}$ & $58(15-84)$ & $\begin{array}{c}\text { Gemtuzumab ozogamicin } \\
\text { (varying dose schedules) + } \\
\text { induction chemotherapy vs. } \\
\text { induction chemotherapy alone. }\end{array}$ & $\begin{array}{c}\mathbf{C R}+\mathbf{C R p} \\
\text { OR } 0.91[0.77-1.07](p= \\
0.3)\end{array}$ & $\begin{array}{c}\text { RFS } \\
\text { OR } 0.84[0.76-0.92](p=0.0003)\end{array}$ & $\begin{array}{c}\text { OS } \\
\text { Median (All): } 22.5 \text { mo } \\
\text { OR } 0.85[0.77-0.94](p=0.002) \\
\text { Fav Cyto } \\
\text { OR } 0.47[0.31-0.74](p=0.0006) \\
\text { Intermed Cyto } \\
\text { OR } 0.84[0.75-0.95](p=0.005)\end{array}$ \\
\hline $\begin{array}{l}\text { ALFA-0701; Lambert et al. } \\
\text { [47] }\end{array}$ & $\begin{array}{c}\text { III, } 271 \text { adult patients ( } 50-70 \text { years old) } \\
\text { with de novo AML fit to receive } 7+3 \\
\text { induction chemotherapy in modified ITT } \\
\text { analysis }\end{array}$ & $\begin{array}{c}62(50-70) \\
\text { Gemtuzumab } \\
62(50-70) \\
\text { Control } \\
61(50-70)\end{array}$ & Same as above. & $\begin{array}{c}\text { CR }+ \text { CRp } \\
81.5 \% \text { vs. } 74.1 \% \\
(p=0.15) \\
\text { CR } 70.4 \% \text { vs. } 69.9 \%\end{array}$ & $\begin{array}{c}\text { Median EFS } \\
17.3 \text { mo vs. } 9.5 \text { mo } \\
\text { HR } 0.56[0.42-0.76](p=0.0002) \\
\text { Median RFS } 28.0 \text { mo vs. } 11.4 \\
\text { mo } \\
\text { HR } 0.53[0.36-0.76](p=0.0006)\end{array}$ & $\begin{array}{c}\text { Median OS } \\
27.5 \text { mo vs. } 21.8 \mathrm{mo} \\
\text { HR } 0.81[0.60-1.09](p=0.16)\end{array}$ \\
\hline RATIFY; Stone et al. [48] & $\begin{array}{l}\text { III, } 717 \text { adult patients (age } 18-59 \text { years } \\
\text { old) with newly diagnosed, } \\
\text { FLT3-mutated AML fit to receive } 7+3 \\
\text { induction chemotherapy }\end{array}$ & $\begin{array}{c}47.9(18-60.9) \\
\text { Midostaurin } \\
47.1(19-59.8) \\
\text { Placebo } \\
48.6(18-60.9)\end{array}$ & $\begin{array}{l}\text { Midostaurin } 50 \mathrm{mg} \text { PO BID vs. } \\
\text { placebo PO BID on days } 8-21 \text { of } \\
\text { induction and consolidation } \\
\text { cycles. } \\
\text { All patients received } \\
\text { daunorubicin } 60 \mathrm{mg} / \mathrm{m}^{2} \text { on } \\
\text { days } 1-3 \text { and cytarabine } 200 \\
\mathrm{mg} / \mathrm{m}^{2} \text { on days } 1-7 .\end{array}$ & CR $59 \%$ vs. $54 \%(p=0.15)$ & $\begin{array}{c}\text { Median EFS } 8.2 \text { mo vs. } 3.0 \text { mo } \\
\text { HR } 0.78[0.66-0.93] \\
(p=0.002) \\
4 \text {-yr EFS } \\
28.2 \% \text { vs. } 20.6 \% \\
\text { Median DFS } \\
26.7 \text { mo vs. } 15.5 \text { mo }(p=0.01)\end{array}$ & $\begin{array}{c}\text { Median OS } \\
74.7 \text { mo vs. } 25.6 \mathrm{mo} \\
\text { HR 0.78 [0.63-0.96] } \\
(p=0.009) \\
4 \text {-yr OS } 51.4 \% \text { vs. } 44.3 \%\end{array}$ \\
\hline
\end{tabular}


Table 1. Cont

\begin{tabular}{|c|c|c|c|c|c|c|}
\hline Study/Author & Phase/Population & Median Age (Years) [Range] & Study Medication & CR & DFS/EFS/PFS/RFS & OS \\
\hline $\begin{array}{l}\text { NCT00788892; } \\
\text { Lancet et al. [49] }\end{array}$ & $\begin{array}{l}\text { II, adult patients (60-75 years old) with } \\
\text { newly diagnosed AML fit to receive } 7+3 \\
\text { induction chemotherapy }\end{array}$ & $\begin{array}{c}\text { CPX-351: } \\
68(60-77) \\
7+3: 68(61-77)\end{array}$ & $\begin{array}{c}\text { CPX-351 on days } 1,3,5 \text { of } \\
\text { initial induction vs } \\
\text { daunorubicin } 60 \mathrm{mg} / \mathrm{m}^{2} \text { on } \\
\text { days } 1-3 \text { and cytarabine } 100 \\
\mathrm{mg} / \mathrm{m}^{2} \text { on days } 1-7 \text { of } \\
\text { induction cycle. } \\
\text { Consolidation cycles with } \\
\text { CPX-351 or } 5+2 \text { or IDAC. }\end{array}$ & $\begin{array}{c}\text { CR + CRi } \\
\text { All } 66.7 \% \text { vs. } 51.2 \% \\
\text { sAML } 57.9 \% \text { vs. } 31.6 \% \\
\text { All } 48.8 \% \text { vs. } 48.8 \% \\
\text { sAML } 36.7 \% \text { vs. } 31.6 \%\end{array}$ & $\begin{array}{c}\text { Median EFS } \\
\text { All } 6.5 \text { mo vs. } 2.0 \mathrm{mo} \\
(p=0.36) \\
\text { sAML } 4.5 \text { mo vs. } 1.3 \mathrm{mo} \\
\text { HR } 0.59(p=0.08)\end{array}$ & $\begin{array}{c}\text { Median OS } \\
\begin{array}{c}14.7 \text { mo vs. } 12.9 \mathrm{mo} \\
(p=0.61)\end{array} \\
\text { sAML } 12.1 \text { mo vs. } 6.1 \mathrm{mo} \\
\text { HR } 0.46(p=0.01)\end{array}$ \\
\hline $\begin{array}{l}\text { NCT01696084; } \\
\text { Lancet et al. [50] }\end{array}$ & $\begin{array}{l}\text { III, } 309 \text { adult patients ( } 60-75 \text { years old) } \\
\text { with newly diagnosed } \\
\text { "high-risk"/sAML fit to receive } 7+3 \\
\text { induction chemotherapy }\end{array}$ & $\begin{array}{c}\text { CPX-351 } \\
67.8 \text { (NR) } \\
7+367.7 \text { (NR) }\end{array}$ & Same as above. & $\begin{array}{c}\text { CR }+ \text { CRi } 47.7 \% \text { vs. } 33.3 \% \\
(p=0.016) \\
\text { CR } 37.3 \% \text { vs. } 25.6 \%(p= \\
0.04)\end{array}$ & $\begin{array}{c}\text { Median EFS } 2.53 \text { mo vs. } 1.31 \\
\text { mo } \\
\text { HR } 0.74[0.58-0.96](p=0.021)\end{array}$ & $\begin{array}{c}\text { Median OS } 9.56 \text { mo vs. } 5.95 \mathrm{mo} \\
\text { HR } 0.69[0.52-0.90](p=0.003) \\
\text { 1-yr OS } 41.5 \% \text { vs. } 27.6 \% \\
2-y r \text { OS } 31.1 \% \text { vs. } 12.3 \%\end{array}$ \\
\hline Benitez et al. [51] & $\begin{array}{l}\text { Retrospective, } 169 \text { adult patients ( } \geq 18 \\
\text { years old) with newly diagnosed sAML }\end{array}$ & $\begin{array}{c}\text { CPX-351 } \\
67(31-80) \\
\text { HIDAC-based } \\
67(27-82)\end{array}$ & $\begin{array}{l}\text { CPX-351 vs. regimens with } \\
\text { purine analog and HIDAC. }\end{array}$ & $\begin{array}{c}\text { CR + CRi } 47.9 \% \text { vs. } 62.7 \% \\
(p=0.002 \text { for } \\
\text { non-inferiority) } \\
\text { CR } 41.5 \% \text { vs. } 49.3 \%(p= \\
0.352) \\
\end{array}$ & $\begin{array}{c}\text { Median EFS } \\
4.11 \text { mo vs. } 5.56 \mathrm{mo}(p=0.48)\end{array}$ & $\begin{array}{c}\text { Median OS } 9.1 \text { mo vs. } 9.8 \mathrm{mo} \\
(p=0.88) \\
\text { 30-day mortality } \\
8.5 \% \text { vs. } 1.3 \%(p=0.039)\end{array}$ \\
\hline FOSSIL; Vulaj et al. [52] & $\begin{array}{l}\text { Retrospective, } 106 \text { adult patients ( }>18 \\
\text { years old) with treatment-naïve sAML }\end{array}$ & $\begin{array}{c}\text { FLAG } \\
63(27-82) \\
7+360(21-76)\end{array}$ & FLAG vs. $7+3$ & $\begin{array}{c}\text { CR + CRi } 65 \% \text { vs. } 45 \%(p= \\
0.071) \\
\text { ORR (CR + CRi }+ \text { MLFS) } \\
70 \% \text { vs. } 48 \%(p=0.043)\end{array}$ & $\begin{array}{c}\text { Median RFS } \\
4 \text { mo vs. } 5 \text { mo }(p=0.101)\end{array}$ & $\begin{array}{c}\text { Median OS } 8.5 \text { mo vs. } 9.1 \mathrm{mo} \\
\qquad(p=0.798)\end{array}$ \\
\hline $\begin{array}{l}\text { NCT03214562; } \\
\text { Lachowiez et al. [53] }\end{array}$ & $\begin{array}{l}\mathrm{Ib} / \mathrm{II} \text {, cohort of } 24 \text { adult patients ( }>18 \\
\text { years old) with newly diagnosed AML }\end{array}$ & 44 & FLAG-IDA + Venetoclax. & $\mathbf{C R}+\mathbf{C R i}+\mathbf{C R h} 89 \%$ & Median EFS Not reached & $\begin{array}{c}\text { Median OS Not reached } \\
\text { 1-yr OS } 92 \%\end{array}$ \\
\hline
\end{tabular}


In contrast, the phase 3 NCRI-AML17 study showed no difference in the CR rates or 2-year OS between daunorubicin $60 \mathrm{mg} / \mathrm{m}^{2}$ and $90 \mathrm{mg} / \mathrm{m}^{2}$ induction regimens, but higherdose daunorubicin did result in a higher 60-day mortality $(10 \%$ vs. 5\%, $p=0.001)$ [42]. This study was conducted in largely younger patients, utilized a lower dose of cytarabine (100 $\mathrm{mg} / \mathrm{m}^{2}$ continuous for seven days), and most notably was followed by a second daunorubicin-containing induction course [42]. While this may suggest that $90 \mathrm{mg} / \mathrm{m}^{2}$ is not superior to $60 \mathrm{mg} / \mathrm{m}^{2}$, the second induction also raises the question if there is a dose threshold for the optimal effect.

A phase 3 study comparing idarubicin $12 \mathrm{mg} / \mathrm{m}^{2}$ on days $1-3$ to daunorubicin $90 \mathrm{mg} / \mathrm{m}^{2}$ on days $1-3$ in patients age 15-65 years old showed no differences in the CR rates, relapse, or survival [43]. However, a higher EFS and OS were seen in patients with FMS-like tyrosine kinase 3-internal tandem duplication (FLT3-ITD) mutations who received daunorubicin compared with idarubicin [43]. ALFA-9801 found no difference in EFS, relapse rates, or OS between daunorubicin $80 \mathrm{mg} / \mathrm{m}^{2}$ on days $1-3$, idarubicin $12 \mathrm{mg} / \mathrm{m}^{2}$ on days $1-4$ or idarubicin $12 \mathrm{mg} / \mathrm{m}^{2}$ on days $1-3$ in patients between $50-70$ years old. Notably, both idarubicin arms resulted in higher CR rates than daunorubicin [44].

The addition of gemtuzumab ozogamicin (GO), an antibody-drug conjugate that binds to CD33, presents another alternative to induction therapy in older patients. The ALFA-0701 study evaluated the impact of the addition of GO $3 \mathrm{mg} / \mathrm{m}^{2}$ ( $\max 5 \mathrm{mg}$ ) on days 1,4 , and 7 to a backbone of daunorubicin $60 \mathrm{mg} / \mathrm{m}^{2}$ on days $1-3$ and cytarabine $200 \mathrm{mg} / \mathrm{m}^{2}$ continuous on days 1-7 followed by two consolidation courses composed of daunorubicin and cytarabine with or without GO [45].

During the initial analysis, the addition of GO resulted in a significantly better 2year EFS (40.8\% vs. 17.1\%, 0.0003), 2-year OS (53.2\% vs. $41.9 \%, p=0.0368)$, and 2-year relapse-free survival (RFS) $(50.3 \%$ vs. $22.7 \%, p=0.0003)$ compared with the chemotherapy backbone alone, without worse treatment-related mortality (TRM) [45]. In subgroup analyses, patients with favorable and intermediate risk cytogenetics appeared to preferentially benefit from the addition of GO [45]. A subsequent meta-analysis also confirmed improvement in both RFS and OS in patients without adverse cytogenetics [46]. However, this meta-analysis was performed prior to the final analysis of ALFA-0701, which reported that the significant OS benefit did not persist [47].

For patients with FLT3-ITD, the standard of care is based upon the results of the phase 3 RATIFY trial comparing daunorubicin $60 \mathrm{mg} / \mathrm{m}^{2}$ on days $1-3$ and cytarabine $200 \mathrm{mg} / \mathrm{m}^{2}$ continuously on days 1-7 with and without midostaurin $50 \mathrm{mg}$ by mouth twice daily on days 8-21 of induction. Additional consolidation courses with and without midostaurin were also a part of the protocol [48]. This resulted in improved EFS and OS. This study, however, was potentially limited by a control arm in which daunorubicin was only dosed at $60 \mathrm{mg} / \mathrm{m}^{2}$, which in patients 65 years and younger could be considered non-standard of care [48].

Lastly, are the intensive treatment options for secondary AML (sAML) including therapy-related AML, antecedent MDS/CMML, and AML with myelodysplastic related changes. The current standard of care for sAML patients 60 years and older is CPX-351, or liposomal formulation of cytarabine and daunorubicin in a 5:1 fixed molar ratio. The phase 2 study initially reported improved response rates $(57.6 \%$ vs. $31.6 \%, p=0.06$ with pre-defined one-sided $p$-value for significance of $p<0.1$ ) without significantly worse TRM, and no improvement in EFS or OS [49] compared to '7+3' arm (daunorubicin $60 \mathrm{mg} / \mathrm{m}^{2}$ and cytarabine $100 \mathrm{mg} / \mathrm{m}^{2}$ ).

The authors did not provide extensive reasoning for their $p$-value selection, only noting that a less stringent $p$-value was selected to provide a basis for phase 3 study design, rather than replace it altogether. The subsequent phase 3 study, in contrast, did show improvement response rates $(47.7 \%$ vs. $33.3 \%, p=0.016)$, median EFS (2.53 months vs. 1.31 months, $p=0.021)$ and median OS (9.56 months vs. 5.95 months, $p=0.003)$ [50]. The OS benefit was seen amongst all age subgroups. The CPX-351 arm also experienced prolonged time to neutrophil and platelet recovery, and the study had some additional issues, including sub-optimal control arm selection that have raised concern about its generalizability [51]. 
CPX-351 is now being studied in combination with the BCL-2 inhibitor, venetoclax in frontline and relapsed settings [54].

A retrospective study comparing the outcomes of high-dose cytarabine (HIDAC) based regimens and CPX-351 found no difference in the CR/CRi (complete remission with incomplete count recovery) or median OS between HIDAC and CPX-351, with a lower 30-day mortality for patients receiving HIDAC ( $1.3 \%$ vs. $8.5 \%, p=0.039)$ [51]. The FOSSIL study compared FLAG (fludarabine, high-dose cytarabine and g-CSF) with ' $7+3$ ' in sAML [52].

FLAG resulted in a higher ORR ( $70 \%$ vs. $48 \%, p=0.043)$, shorter duration of neutropenia, and higher rates of consolidative therapy, but no difference in the overall survival compared with '7+3' [52]. Unfortunately, no randomized trial has been published comparing CPX-351 and FLAG or HIDAC; however, these regimens could be considered in resource-poor populations where CPX-351 is not readily available. An early phase study combining FLAG-IDA and venetoclax demonstrated early promise in both de novo and sAML but still requires more robust numbers [53].

\subsection{Hypomethylating Agent (HMA)-Based Regimens}

Since the FDA approvals of azacitidine in 2004 and decitabine in 2006 for the treatment of AML, they have served as the backbone of treatment for older or "unfit" adults. In recent years, they have been combined with multiple targeted agents in an effort to bolster responses and provide effective alternatives for those not receiving induction chemotherapy or as treatment for relapsed/refractory disease. Here, we will discuss some of these combinations.

\subsubsection{HMA Only}

5-Azacitidine was determined to be an effective in patients with AML in the AZAPH-GL-2003 and AZA-AML-001 studies [55,56]. Fenaux et al. reported the phase 3 results (Table 2) of patients with high-risk MDS and AML with low blast count (20-30\%) comparing 5-azacitidine with conventional care regimens (CCRs) at that time, namely intensive chemotherapy, low-dose cytarabine (LDAC), and best supportive care (BSC) [55]. Azacitidine significantly improved the median overall survival compared with CCRs (24.5 months vs. 16.0 months, $p=0.005$ ) and was associated with fewer days spent in the hospital in a patient population with a median age of 70 years [55].

The AML-001 trial compared azacitidine with the aforementioned CCRs in adults with AML with a high-blast count (>30\%) [56]. While the overall cohort did not meet statistical significance in the median OS (10.4 months vs. 6.5 months, $p=0.1009)$, the subset of patients who did not receive subsequent AML directed therapy did show an improved median OS with azacitidine compared with CCRs (12.1 months vs. 6.9 months, $p=0.019$ ), which was attributed to the unbalanced use of azacitidine in the second line in CCRs regimens compared with the azacitidine arm (13.3\% vs. $4.6 \%)$ with the comparable use of other agents (LDAC or decitabine) between the two arms [56].

A subsequent cytogenetic analysis of this study found significant improvement in the survival for patients with adverse cytogenetics $(-5 / 5 q-,-7 / 7 q-, 17 p$ abnormalities, and complex or monosomal karyotypes) [57]. The overall response [CR+CRi (complete remission with incomplete hematologic recovery)] rates were not significantly different for azacitidine (27.8\%) and CCRs (25.1\%). 
Table 2. Hypomethylator-based frontline regimens for adults with Acute Myeloid Leukemia with an emphasis on older adults.

\begin{tabular}{|c|c|c|c|c|c|c|}
\hline Study/Author & Phase/Population & Median Age (Years) [Range] & Study Medications & CR & DFS/EFS/PFS/RFS & os \\
\hline \multicolumn{7}{|c|}{ Hypomethylating Agent (HMA)-Based Regimens } \\
\hline \multirow{4}{*}{$\begin{array}{l}\text { AZA-PH-GL-2003; Fenaux } \\
\text { et al. [55] }\end{array}$} & \multirow{4}{*}{$\begin{array}{l}\text { III parallel group study, } 113 \text { adult } \\
\text { patients ( } \geq 18 \text { years old) with newly } \\
\text { diagnosed AML (blast count } 20-30 \% \text { ) }\end{array}$} & $\begin{array}{l}\text { Azacitidine: } \\
70(52-80)\end{array}$ & & \multirow{4}{*}{$\begin{array}{c}\text { Morphologic CR: } 18 \% \text { vs. } \\
16 \%(p=0.80)\end{array}$} & \multirow{4}{*}{ Not reported } & \\
\hline & & $\begin{array}{l}\text { LDAC: } \\
71(56-83)\end{array}$ & $\begin{array}{l}\text { 5-Azacitidine } 75 \mathrm{mg} / \mathrm{m} 2 \text { on } \\
\text { days } 1-7 \text { of } 28 \text {-day cycle vs. } \\
\text { CCRs (LDAC, BSC, or }\end{array}$ & & & $\begin{array}{c}\text { Median OS: } \\
24.5 \text { mo vs. } 14.6 \text { mo HR } 0.47 \\
{[0.28-0.79](p=0.005)}\end{array}$ \\
\hline & & $\begin{array}{l}\text { BSC only: } \\
70(56-81)\end{array}$ & $\begin{array}{l}\text { Anthracycline }+ \text { Cytarabine } \\
\text { based intensive chemo) }\end{array}$ & & & $\begin{array}{c}\text { 2-yr OS: } \\
50 \% \text { vs. } 16 \%(p=0.001)\end{array}$ \\
\hline & & $\begin{array}{c}\text { Anthracycline + Cytarabine: } \\
65(50-76)\end{array}$ & & & & \\
\hline \multirow{4}{*}{$\begin{array}{l}\text { AZA-AML-001; Dombret } \\
\text { et al. [56] }\end{array}$} & \multirow{4}{*}{$\begin{array}{l}\text { III parallel group study, } 488 \text { adult } \\
\text { patients ( } \geq 65 \text { years old) with newly } \\
\text { diagnosed AML (blast count }>30 \% \text { ) }\end{array}$} & $\begin{array}{c}\text { Azacitidine: } \\
75 \text { (64-91) }\end{array}$ & \multirow{4}{*}{$\begin{array}{l}\text { 5-Azacitidine } 75 \mathrm{mg} / \mathrm{m}^{2} \text { on } \\
\text { days } 1-7 \text { of } 28 \text {-day cycle vs. } \\
\text { CCRs (LDAC, BSC, or } \\
\text { Anthracycline + Cytarabine } \\
\text { based intensive chemo) }\end{array}$} & \multirow{4}{*}{$\begin{array}{c}\text { CR + CRi: } 27.8 \% \text { vs. } 25.1 \text { (all } \\
\text { CCRs) }(p=0.5384) \\
\text { CR: } 19.5 \% \text { vs. } 21.9 \%(p= \\
0.5766)\end{array}$} & \multirow{4}{*}{$\begin{array}{c}\text { Median EFS: } \\
6.7 \text { mo vs. } 4.6 \text { mo }(p=0.1495) \\
\text { Median RFS: } \\
9.3 \text { mo vs. } 10.5 \text { mo }(p= \\
0.5832)\end{array}$} & \multirow{4}{*}{$\begin{array}{l}\text { Median OS: } 10.4 \text { mo vs. } 6.5 \mathrm{mc} \\
\qquad(p=0.1009) \\
\text { Median OS (subset censored } \\
\text { at time of subsequent AML } \\
\text { therapy): } 12.1 \text { mo vs. } 6.9 \mathrm{mo} \\
\text { HR } 0.76[0.60-0.96](p=0.019)\end{array}$} \\
\hline & & $\begin{array}{l}\text { LDAC: } \\
75 \text { (65-88) }\end{array}$ & & & & \\
\hline & & $\begin{array}{l}\text { BSC only: } \\
78(67-89)\end{array}$ & & & & \\
\hline & & $\begin{array}{c}\text { Anthracycline + Cytarabine: } \\
60.5(65-81)\end{array}$ & & & & \\
\hline $\begin{array}{c}\text { NCT02203773, Dinardo et al. } \\
\text { [59] }\end{array}$ & $\begin{array}{c}\text { Ib, } 145 \text { adult patients ( } \geq 60 \text { years old) } \\
\text { with newly diagnosed AML who were } \\
\text { ineligible for standard induction } \\
\text { chemotherapy }\end{array}$ & $74(65-86)$ & Same as above & $\begin{array}{c}\text { CR + CRi: } 67 \% \\
\text { CR: } 37 \%\end{array}$ & Not reported & Median OS: $17.5 \mathrm{mo}$ \\
\hline \multirow{3}{*}{$\begin{array}{c}\text { NCT02203773, Pollyea et al. } \\
\text { [60] }\end{array}$} & \multirow{3}{*}{$\begin{array}{l}\mathrm{Ib} \text {, cohort of } 115 \text { adult patients ( } \geq 65 \\
\text { years old) with newly diagnosed AML } \\
\text { who were ineligible for standard } \\
\text { induction chemotherapy }\end{array}$} & $\begin{array}{l}\text { Ven + AZA: } \\
75(61-90)\end{array}$ & $\begin{array}{l}\text { Venetoclax } 400 \mathrm{mg} \text { PO daily }+ \\
\text { HMA (Decitabine } 20 \mathrm{mg} / \mathrm{m}^{2} \text { on }\end{array}$ & $\frac{\text { Ven+AZA }}{\text { CR + CRi: } 71 \%}$ & \multirow{3}{*}{ Not reported } & $\begin{array}{c}\text { Ven+AZA } \\
\text { Median OS: } 16.4 \text { mo }\end{array}$ \\
\hline & & $\begin{array}{l}\text { Ven + Dec: } \\
72(65-86)\end{array}$ & $\begin{array}{l}5 \text {-Azacitidine } 75 \mathrm{mg} / \mathrm{m}^{2} \text { on } \\
\text { days } 1-7 \text { of } 28 \text {-day cycle) }\end{array}$ & $\underset{\text { CR + CRi: } 74 \%}{\text { Ven+Dec }}$ & & $\begin{array}{c}\text { Ven+Dec } \\
\text { Median OS: } 16.2 \mathrm{mo}\end{array}$ \\
\hline & & & & CR: $55 \%$ & & \\
\hline
\end{tabular}


Table 2. Cont

\begin{tabular}{|c|c|c|c|c|c|c|}
\hline Study/Author & Phase/Population & Median Age (Years) [Range] & Study Medications & CR & DFS/EFS/PFS/RFS & os \\
\hline VIALE-A; Dinardo et al. [61] & $\begin{array}{l}\text { III, } 431 \text { adult patients ( } \geq 18 \text { years old) } \\
\text { with newly diagnosed AML who were } \\
\text { ineligible for standard induction } \\
\text { chemotherapy }\end{array}$ & $\begin{array}{c}76(49-91) \\
\text { AZA + Ven: } \\
76 \text { (49-91) } \\
\text { AZA + Placebo: } \\
76(60-90)\end{array}$ & $\begin{array}{c}\text { 5-Azacitidine + Venetoclax } 400 \\
\text { mg PO daily vs. 5-Azacitidine + } \\
\text { Placebo }\end{array}$ & $\begin{array}{c}\text { CR + CRi: } 66.4 \% \text { vs. } 28.3 \%(p \\
<0.001) \\
\text { CR: } 36.7 \% \text { vs. } 17.9 \%(p< \\
0.001)\end{array}$ & $\begin{array}{c}\text { Median EFS: } \\
9.8 \text { mo vs. } 7.0 \mathrm{mo} \\
\text { HR } 0.63[0.50-0.80](p< \\
0.001)\end{array}$ & $\begin{array}{c}\text { Median OS: } \\
14.7 \text { mo vs. } 9.6 \text { mo } \\
\text { HR } 0.66[0.52-0.85](p<0.001)\end{array}$ \\
\hline $\begin{array}{l}\text { DACO-016; Kantarjian et al. } \\
\text { [62] }\end{array}$ & $\begin{array}{l}\text { III, } 485 \text { adult patients ( } \geq 65 \text { years old) } \\
\text { with newly diagnosed AML who were } \\
\text { ineligible for standard induction } \\
\text { chemotherapy }\end{array}$ & $\begin{array}{c}73 \text { (64-91) } \\
\text { Decitabine: } \\
73 \text { (64-89) } \\
\text { BSC: } 75 \text { (66-86) } \\
\text { LDAC: } \\
73 \text { (64-91) }\end{array}$ & $\begin{array}{c}\text { Decitabine } 20 \mathrm{mg} / \mathrm{m}^{2} \text { on days } \\
1-5 \text { of } 28 \text {-day cycle vs. } \\
\text { BSC/LDAC }\end{array}$ & $\begin{array}{c}\text { CR + CRp: } 17.8 \% \text { vs. } 7.8 \% \\
\text { OR } 2.5[1.4-4.8] \\
(p=0.001) \\
\text { CR + CRi + CRp: } 27.7 \% \text { vs. } \\
10.6 \% \\
\text { CR: } 15.7 \% \text { vs. } 7.4 \%\end{array}$ & Not reported & $\begin{array}{l}\text { Median OS (planned analysis): } \\
7.7 \text { mo vs. } 5.0 \text { mo }(p=0.108) \\
\text { Median OS (unplanned } \\
\text { analysis): } 7.7 \text { mo vs. } 5.0 \text { mo } \\
\text { HR } 0.82[0.68-0.99] \\
(p=0.037)\end{array}$ \\
\hline $\begin{array}{l}\text { NCT03404193; } \\
\text { Maiti et al. [63] }\end{array}$ & $\begin{array}{l}\text { II, cohort of } 12 \text { adult patients ( }>60 \\
\text { years old) with newly diagnosed AML }\end{array}$ & $70(69-78)$ & $\begin{array}{l}\text { 5-day Decitabine + FLT3 } \\
\text { inhibitor + Venetoclax }\end{array}$ & $\begin{array}{c}\text { CR + CRp + CRi: } 92 \% \\
\text { CR: } 75 \%\end{array}$ & $\begin{array}{c}\text { 18-mo PFS: } 59 \% \\
\text { Median PFS: Not reached }\end{array}$ & $\begin{array}{c}\text { 2-yr OS: } 80 \% \\
\text { Median OS: Not reached }\end{array}$ \\
\hline $\begin{array}{l}\text { NCT00492401; } \\
\text { Blum et al. [64] }\end{array}$ & $\begin{array}{l}\text { II, adult patients ( } \geq 60 \text { years old) with } \\
\text { newly diagnosed AML who were } \\
\text { ineligible for or refused standard } \\
\text { induction chemotherapy }\end{array}$ & $74(60-85)$ & $\begin{array}{l}\text { Decitabine } 20 \mathrm{mg} / \mathrm{m}^{2} \text { on days } \\
1-10 \text { of } 28 \text {-day cycle }\end{array}$ & CR: $47 \%$ & $\begin{array}{l}\text { Median DFS: } \\
\quad 46 \mathrm{wks}\end{array}$ & Median OS: 55 wks \\
\hline Ritchie et al. [65] & $\begin{array}{c}52 \text { adult patients ( }>60 \text { years old, } \\
\text { included } 2 \text { patients under } 60 \text { with } \\
\text { numerous comorbidities) with newly } \\
\text { diagnosed AML } \\
\end{array}$ & $75(45-91)$ & $\begin{array}{l}\text { Decitabine } 20 \mathrm{mg} / \mathrm{m}^{2} \text { on days } \\
1-10 \text { of } 28 \text {-day cycle }\end{array}$ & CR: $40 \%$ & Not reported & Median OS: 318 days \\
\hline $\begin{array}{l}\text { NCT01687400; } \\
\text { Welch et al. [66] }\end{array}$ & $\begin{array}{l}\text { II, } 116 \text { adult patients with newly } \\
\text { diagnosed AML ( } \geq 60 \text { years old), } \\
\text { relapsed AML }(\geq 18 \text { years old), or } \\
\text { transfusion-dependent AMS }\end{array}$ & $74(29-88)$ & 10-day Decitabine & $\begin{array}{c}\text { CR + CRi: } 34 \% \\
\text { CR: } 13 \%\end{array}$ & Not reported & $\begin{array}{c}\text { Median OS: } \\
\text { Unfav Risk } 11.6 \text { mo } \\
\text { Fav/Int Risk } \\
10.0 \text { mo TP53 Mutants } \\
12.7 \text { mo } \\
\text { TP53 Wild Type } 15.4 \text { mos }\end{array}$ \\
\hline Dinardo et al. [67] & $\begin{array}{l}\text { II, cohorts with a total of } 85 \text { adult } \\
\text { patients ( } \geq 60 \text { years old) with newly } \\
\text { diagnosed AML or untreated sAML } \\
\text { who were ineligible for standard } \\
\text { induction chemotherapy }\end{array}$ & $72(68-78)$ & $\begin{array}{c}\text { 10-day Decitabine }+ \\
\text { Venetoclax } 400 \mathrm{mg} \text { PO daily }\end{array}$ & $\begin{array}{c}\text { CR + CRi: } 81 \% \\
\text { CR: } 61 \%\end{array}$ & Not reported & $\begin{array}{c}\text { Median OS for newly } \\
\text { diagnosed AML: } 18.1 \mathrm{mo} \\
\text { Median OS for untreated } \\
\text { sAML: } 7.8 \mathrm{mo}\end{array}$ \\
\hline
\end{tabular}


Table 2. Cont

\begin{tabular}{|c|c|c|c|c|c|c|}
\hline Study/Author & Phase/Population & Median Age (Years) [Range] & Study Medications & CR & DFS/EFS/PFS/RFS & Os \\
\hline Maiti et al. [68] & $\begin{array}{l}\text { Retrospective propensity-score } \\
\text { matched, } 170 \text { adult patients with } \\
\text { newly diagnosed AML }\end{array}$ & $\begin{array}{l}\text { 10-day Decitabine + } \\
\text { Venetoclax: } \\
72(69-78) \\
\\
\text { Intensive chemotherapy: } \\
73(67-76)\end{array}$ & $\begin{array}{c}\text { 10-day Decitabine }+ \\
\text { Venetoclax } 400 \mathrm{mg} \text { PO daily vs. } \\
\text { intensive chemotherapy } \\
\text { containing at least cytarabine } \geq \\
1 \mathrm{~g} / \mathrm{m}^{2} / \mathrm{d} \text { in combination with } \\
\text { other agents }\end{array}$ & $\begin{array}{c}\text { CR + CRi: } 81 \% \text { vs. } 52 \% \\
\text { OR } 3.78[1.81-7.88](p<0.001) \\
\text { CR: } 62 \% \text { vs. } 42 \% \\
\text { OR } 2.21[1.18-4.16](p=0.01)\end{array}$ & $\begin{array}{l}\text { Median EFS: } \\
9.0 \text { mo vs. } 2.3 \text { mo } \\
\text { HR } 0.47[0.33-0.67] \\
\quad(p<0.0001)\end{array}$ & $\begin{array}{c}\text { Median OS: } \\
12.4 \text { mo vs. } 5.0 \text { mo } \\
\text { OR } 0.48[0.29-0.79](p<0.01)\end{array}$ \\
\hline Nand et al. [69] & $\begin{array}{l}\text { II, } 20 \text { adult patients ( } \geq 56 \text { years old) } \\
\text { with newly diagnosed AML or RAEB-I } \\
\text { or RAEB-II MDS }\end{array}$ & $76(64-83)$ & $\begin{array}{c}\text { Azacitidine } 75 \mathrm{mg} / \mathrm{m}^{2} \text { on days } \\
1-7 \text { and } \mathrm{Gemtuzumab} \\
\text { ozogamicin } 3 \mathrm{mg} / \mathrm{m}^{2} \text { on day } 8 \\
\text { of } 28 \text {-day cycle }+ \text { Hydroxyurea } \\
\text { (to lower WBC count) }\end{array}$ & $\begin{array}{l}\text { CR + CRi: } 70 \% \\
\text { CR: } 55 \%\end{array}$ & Not reported & $\begin{array}{l}\text { Median OS: } \\
\quad 11 \mathrm{mo}\end{array}$ \\
\hline $\begin{array}{l}\text { NCT00658814; } \\
\text { Nand et al. [70] }\end{array}$ & $\begin{array}{l}\text { II, } 142 \text { adult patients ( } \geq 60 \text { years old) } \\
\text { with newly diagnosed AML } \\
\text { Favorable risk: } 60-69 \text { years old or } \\
\text { Zubrod PS 0 or } 1 \text { ( } 83 \text { pts) } \\
\frac{\text { Adverse risk: } \geq 70 \text { years old AND }}{\text { Zubrod PS } 2-3 \text { ( } 59 \text { pts) }}\end{array}$ & $\begin{array}{l}\frac{\text { Favorable Risk }}{71(60-88)} \\
\frac{\text { Adverse Risk }}{75(70-87)}\end{array}$ & $\begin{array}{c}\text { Azacitidine } 75 \mathrm{mg} / \mathrm{m}^{2} \text { on days } \\
1-7 \text { and } \mathrm{Gemtuzumab} \\
\text { ozogamicin } 3 \mathrm{mg} / \mathrm{m}^{2} \text { on day } 8 \\
\text { of } 28 \text {-day cycle+ Hydroxyurea } \\
\text { (to lower WBC count) }\end{array}$ & $\begin{array}{c}\text { Favorable Risk } \\
\text { CR + CRi: } 44 \% \\
\text { CR: } 28 \% \\
\text { Adverse Risk } \\
\text { CR + CRi: } 35 \% \\
\text { CR: } 20 \%\end{array}$ & $\begin{array}{c}\text { Favorable Risk } \\
\text { Median RFS: } \\
8.3 \text { mo } \\
\\
\text { Adverse Risk } \\
\text { Median RFS: } \\
\quad 7 \text { mo }\end{array}$ & $\begin{array}{c}\text { Adverse Risk } \\
\text { Median OS: } 11 \text { mo } \\
\begin{array}{c}\text { AdverseRisk } \\
\text { Median OS: } \\
11 \mathrm{mo}\end{array}\end{array}$ \\
\hline $\begin{array}{l}\text { NCT02677922; Dinardo et al. } \\
\text { [71] }\end{array}$ & $\begin{array}{l}\mathrm{Ib} \text {, cohort of } 23 \text { adult patients }(\geq 18 \\
\text { years old) with newly-diagnosed, } \\
\text { mutant IDH1 AML ineligible for } \\
\text { induction chemotherapy }\end{array}$ & $\begin{array}{c}76(61-88) \\
52 \% \geq 75 \mathrm{yrs}\end{array}$ & $\begin{array}{l}\text { 5-AZA } 75 \mathrm{mg} / \mathrm{m}^{2} \text { on days } 1-7+ \\
\text { Ivosidenib } 500 \mathrm{mg} \text { daily every } \\
28 \text {-day cycle }\end{array}$ & $\begin{array}{c}\text { CR }+ \text { CRh } 69.6 \% \\
\text { CR } 60.9 \%\end{array}$ & & $\begin{array}{l}\text { Median OS Not reached } \\
\qquad \text { 12-mo OS } 82 \%\end{array}$ \\
\hline $\begin{array}{c}\text { NCT02677922 } \\
\text { (ASH 2019); } \\
\text { Dinardo et al. [72] }\end{array}$ & $\begin{array}{l}\text { I/II, cohort of } 101 \text { adult patients ( } \geq 18 \\
\text { years old) with newly-diagnosed, } \\
\text { mutant IDH2 AML ineligible for } \\
\text { induction chemotherapy }\end{array}$ & $74(62-85)$ & $\begin{array}{c}5 \text {-AZA } 75 \mathrm{mg} / \mathrm{m}^{2} \text { on days } 1-7+ \\
\text { Enasidenib } 100 \mathrm{mg} \text { daily every } \\
28 \text {-day cycle vs. } 5 \text {-AZA } 75 \\
\mathrm{mg} / \mathrm{m}^{2} \text { on days } 1-7 \text { of } 28 \text {-day } \\
\text { cycle }\end{array}$ & $\begin{array}{c}\text { ORR } \\
68 \% \text { vs. } 42 \%(p=0.0155) \\
\text { CR } \\
50 \% \text { vs. } 12 \%(p=0.0002) \\
\end{array}$ & Not reported & Not reported \\
\hline $\begin{array}{l}\text { NCT02677922 (ASCO 2020); } \\
\text { Dinardo et al. [73] }\end{array}$ & $\begin{array}{l}\text { Updated results from phase I/II study } \\
\text { above }\end{array}$ & $75(57-85)$ & Same as above & $\begin{array}{c}\text { ORR } \\
71 \% \text { vs. } 42 \%(p<0.01) \\
\text { CR } \\
53 \% \text { vs. } 12 \%(p<0.01)\end{array}$ & $\begin{array}{c}\text { Median EFS } \\
17.2 \text { vs. } 10.8 \text { mo } \\
\text { HR } 0.59[0.30-1.17](p=0.13)\end{array}$ & $\begin{array}{c}\text { Median OS } \\
22 \text { mo [both arms] }\end{array}$ \\
\hline
\end{tabular}


The role of decitabine in AML was established in the DACO-016 trial [62]. While 5-day decitabine did not show a significant improvement in the median OS (7.7 months vs. $5.0, p=0.108$ ), it did result in an improved CR + CRp (complete remission without platelet recovery) rate $(17.8 \%$ vs. $7.8 \%, p=0.001)$ compared with LDAC or BSC [62].

While these served as good palliative options, they were limited in their ability to achieve $\mathrm{CR}$ and did not produce sustained remissions following treatment cessation. Thus, additional agents were needed to achieve higher remission rates in the hopes of longer remissions and perhaps even consolidation with allogeneic stem cell transplantation.

One approach studied to improve responses to HMAs was the prolongation of decitabine administration, from 5 days to 10 days. In newly-diagnosed AML, this has led to promising improvement in response rates and survival [64]. One study that included over $50 \%$ sAML, 10-day decitabine resulted in a CR rate of $40 \%$ with a median OS of 318 days [65]. Another study reported favorable results in adverse risk AML, particularly TP53-mutated disease. ORR in adverse risk was significantly better than intermediate or favorable-risk disease for those treated with 10-day decitabine (67\% vs. 34\%, $p<0.001)$ [66]. Moreover, TP53-mutated AML had a better ORR than TP53-wild type disease (100\% vs. $41 \%, p<0.001$ ) [66]. This presents a novel option for a patient population with a historically poor prognosis.

\subsubsection{HMA-Venetoclax}

BCL-2 is part of a family of intracellular proteins that inhibit the intrinsic apoptotic pathway for cellular death [74]. The inhibition of BCL-2 was found to result in apoptosis of leukemic blasts in vitro and in pre-clinical models leading to further evaluation [74]. This eventually led to phase $1 \mathrm{~b}$ dose-escalation studies combining decitabine or azacitidine with the BCL-2 inhibitor, venetoclax, in patients age 65 and older with newly diagnosed AML that showed encouraging activity and tolerability [58,59]. The combination of azacitidine and venetoclax had a median CR/CRi duration of 21.9 months and median OS of 16.4 months with largely grade 3 cytopenias and febrile neutropenia rate of $39 \%$.

The smaller cohort who received a combination of decitabine and venetoclax had a median CR/CRi duration of 15.0 months and median OS of 16.2 months with similar cytopenias and a febrile neutropenia rate of $65 \%$ [60]. It led to this combination receiving accelerated approval from the FDA in 2018 and subsequent confirmatory studies. VIALE-A is the phase 3, 2:1 randomized study comparing azacitidine and venetoclax (400 mg daily) with azacitidine and placebo [61].

The median age of the study population was 76 years, and the median OS was significantly greater for azacitidine and venetoclax (14.7 months vs. 9.6 months, $p<0.001)$ [61]. The combination resulted in over a doubling of the CR rate $(36.7 \%$ vs. $17.9 \%, p<0.001)$ and CR/CRi rate $(66.4 \%$ vs. $28.3 \%, p<0.001)$ [61]. Nausea, febrile neutropenia, and grade 3 cytopenias were the predominant toxicities seen with therapy [61]. This has now become the standard of care for patients unfit for intensive chemotherapy with newly diagnosed AML [1].

One variation that produced higher response rates in newly diagnosed, intensive chemotherapy ineligible, AML was 10-day decitabine. Dinardo et al. reported a phase 2 study of 10-day decitabine combined with venetoclax for de novo, secondary, and relapsed/refractory AML with a median age of 71 years and with $30 \%$ of enrolled patients with ECOG PS of 2 or more [67]. ORR were $74 \%$ for the entire cohort, $89 \%$ for de novo AML, and $80 \%$ for untreated sAML with median OS of 18.1 months and 7.8 months, respectively [67]. The median age of treated patients was 72 years old, and $64 \%$ had adverse risk disease by ELN classification [75].

However, this treatment presented high, but manageable, rates of toxicity, including $47 \%$ grade 3 or 4 neutropenia, 38\% neutropenic fever, $83 \%$ of patients with serious adverse events, and a 3.6\% 30-day mortality [67]. The impact of measurable residual disease (MRD) on prognosis was also assessed for this combination. The median time to MRD-negativity was two (2) months, and the median OS was significantly longer for patients achieving MRD-negativity by one (1) month compared with those who were MRD-positive (25.1 
months vs. 3.4 months, $p<0.0001)$ [75]. MRD-negativity by two (2) months was associated with longer median EFS (not reached [NR] vs. 5.8 months, $p<0.001$ ), median RFS (NR vs. 5.2 months, $p=0.004)$, and median OS (25.1 months vs. 7.1 months, $p<0.001)$ compared with patients with MRD-positivity [75].

Lastly, MRD-negative CR was associated with longer median OS than lesser responses (25.1 months vs. 11.6 months, $p<0.0005$ ) [75]. A propensity-matched retrospective study compared patients treated with 10-day decitabine and venetoclax on the phase 2 study with "intensive chemotherapy" (regimens containing $1 \mathrm{~g}$ or more of cytarabine either alone or in combination) [68]. The median age of the study population was 72 years and treatment with 10-day decitabine and venetoclax was associated with lower rates of relapse, lower 30-day mortality, higher CR/CRi rates, and longer survival [68]. The combination of 10-day decitabine and venetoclax is also being studied with the addition of FLT3 inhibitors in FLT3-mutated AML [63].

\subsubsection{HMA-IDH Inhibitors}

Isocitrate dehydrogenase 1 and 2 (IDH1 and IDH2) mutations are present in roughly $5-10 \%$ and $10-20 \%$ of patients newly diagnosed AML, respectively $[9,72,76,77]$. Its frequency makes it a particularly appealing target in patients who are unfit for intensive treatment. Given the early promising data reporting the benefits of both ivosidenib (IDH1inhibitor) and enasidenib (IDH2-inhibitor) in relapsed disease, these two drugs are under investigation in combination with azacitidine for frontline treatment [71-73]. The early phase results for the combination of IDH-inhibitors and azacitidine are promising and are under further investigation in phase 3 (AGILE and IDHENTIFY) studies.

Further use of precision medicine in older patients with newly diagnosed AML based on genomic profiling is under evaluation in the BEAT AML trial with early results showing feasibility of initiating treatment within seven (7) days [78].

\subsection{Other Treatment Approaches, Including Targeted Onotherapy or Other Combinations}

While hypomethylating agents with or without venetoclax are used to treat the majority of older or "unfit" adults, there are several other agents that may be used in patients who are unable to receive these therapies or those with relapsed/refractory disease.

\subsubsection{LDAC +/ - Glasdegib}

Low-dose cytarabine (Ara-C) was compared to BSC with hydroxyurea in patients with AML or MDS unfit for intensive treatment, largely over the age of 60 years (median age 74 years). LDAC resulted in better CR rates $(18 \%$ vs. $1 \%, p=0.00006)$ and overall survival (Table 3) [79]. This led to the approval for LDAC as an alternative for patients unfit for intensive treatment. Later, the addition of glasdegib, a Hedgehog pathway inhibitor, was evaluated for the treatment of patients with AML or high-risk MDS with a median age of 76 years [80]. The median overall survival (8.8 months vs. 4.9 months, $p=0.0004)$ and CR rates $(17 \%$ vs. $2.3 \%, p<0.05)$ were better with LDAC and glasdegib than with LDAC alone [80]. 
Table 3. Other non-intensive non-hypomethylator-based frontline regimens for patients with AML.

\begin{tabular}{|c|c|c|c|c|c|c|}
\hline Study/Author & Phase/Population & Median Age (Years) [Range] & Study Medications & CR & DFS/EFS/PFS/RFS & os \\
\hline \multicolumn{7}{|c|}{ Other Agents } \\
\hline $\begin{array}{l}\text { EORTC-GIMEMA AML-19; } \\
\text { Amadori et al. [81] }\end{array}$ & $\begin{array}{l}\text { III, } 237 \text { adult patients ( }>60 \text { years old) } \\
\text { with newly diagnosed AML }\end{array}$ & $\begin{array}{c}\text { Overall: } \\
77(62-88) \\
\text { GO: } 77(62-88) \\
\text { BSC: } \\
77(66-88)\end{array}$ & $\begin{array}{c}\mathrm{GO} 6 \mathrm{mg} / \mathrm{m}^{2} \text { on day } 1,3 \\
\mathrm{mg} / \mathrm{m}^{2} \text { on day } 8 \text {, followed by } 2 \\
\mathrm{mg} / \mathrm{m}^{2} \text { monthly (up to } 8 \\
\text { months) vs. BSC (Hydroxyurea } \\
\text { could be used in BSC arm only) }\end{array}$ & $\begin{array}{c}\text { CR + CRi: } 27 \% \\
\text { CR: } 8.1 \%\end{array}$ & $\begin{array}{l}\text { Median PFS: } 2.8 \mathrm{mo} \text { (GO } \\
\text { arm only) }\end{array}$ & $\begin{array}{c}\text { Median OS: } 4.9 \text { mo vs. } 3.6 \text { mo } \\
\text { HR } 0.69 \text { [0.53-0.90] }(p=0.005) \\
\text { 1-yr OS: } 24.3 \% \text { vs. } 9.7 \%\end{array}$ \\
\hline $\begin{array}{l}\text { NCRI AML-14; Burnett et al. } \\
{[\text { [79] }}\end{array}$ & $\begin{array}{l}\text { Cohort of } 217 \text { adult patients with } \\
\text { newly diagnosed AML or high-risk } \\
\text { MDS ( }>10 \% \text { BM blasts) who were } \\
\text { deemed unfit for intensive } \\
\text { chemotherapy by local investigator }\end{array}$ & $\begin{array}{l}\quad 74(51-90) \\
4 \text { patients }<60 \text { years old and } \\
165 \text { patients }>70 \text { years old }\end{array}$ & $\begin{array}{l}\text { LDAC } 20 \mathrm{mg} \text { BID for } 10 \text { days } \\
\text { every } 28-42 \text { days vs. BSC } \\
\text { (Hydroxyurea) } \\
\text { Both arms were also } \\
\text { randomized to receive or not } \\
\text { receive ATRA for } 60 \text { days }\end{array}$ & $\begin{array}{c}\text { CR: } 18 \% \text { vs. } 1 \% \\
\text { OR } 0.15[0.06-0.37](p< \\
0.00006)\end{array}$ & Not reported & $\begin{array}{c}\text { Median not reported } \\
\text { OR } 0.60[0.44-0.81](p=0.0009)\end{array}$ \\
\hline $\begin{array}{c}\text { NCT01546038; Cortes et al. } \\
{[80]}\end{array}$ & $\begin{array}{l}\text { II, } 132 \text { adult patients ( } \geq 55 \text { years old) } \\
\text { with newly diagnosed AML (116 pts) } \\
\text { or high-risk MDS who were ineligible } \\
\text { for standard induction chemotherapy }\end{array}$ & $\begin{array}{l}\text { LDAC + Glasdegib: } \\
\quad 77(63-92) \\
\text { LDAC alone: } 75 \text { (58-93) }\end{array}$ & $\begin{array}{l}\text { LDAC } 20 \mathrm{mg} \text { BID for } 10 \text { days of } \\
\text { every } 28 \text {-day cycle + Glasdegib } \\
100 \mathrm{mg} \text { PO daily vs. LDAC } 20 \\
\text { mg BID for } 10 \text { days of every } \\
\text { 28-day cycle }\end{array}$ & CR: $17 \%$ vs. $1 \%(p=0.0142)$ & Not reported & $\begin{array}{c}\text { Median OS: } \\
\text { All: } \\
\text { 8.8 mo vs. } 4.9 \mathrm{mo} \\
\text { HR } 0.513[0.394-0.666](p= \\
0.0004) \\
\text { AML cohort: } \\
\text { 8.3 mo vs. } 4.3 \mathrm{mo} \\
\text { HR } 0.46[0.35-0.62](p=0.0002)\end{array}$ \\
\hline $\begin{array}{l}\text { NCT02287233; } \\
\text { Wei et al. [82] }\end{array}$ & $\begin{array}{l}\mathrm{Ib} / \mathrm{II}, 82 \text { adult patients ( } \geq 60 \text { years old) } \\
\text { with previously untreated AML who } \\
\text { were ineligible for intensive } \\
\text { chemotherapy } \\
49 \% \text { sAML }\end{array}$ & $74(63-90)$ & $\begin{array}{l}\text { LDAC } 20 \mathrm{mg} \text { BID for } 10 \text { days + } \\
\text { Venetoclax } 600 \mathrm{mg} \text { PO daily } \\
\text { every } 28 \text {-day cycle }\end{array}$ & $\begin{array}{c}\text { CR + CRi: } 54 \% \\
\text { CR: } 26 \%\end{array}$ & Not reported & Median OS: 10.1 mo \\
\hline VIALE-C; Wei et al. [83] & $\begin{array}{l}\text { III, } 211 \text { adult patients ( } \geq 18 \text { years old) } \\
\text { with newly diagnosed AML who were } \\
\text { ineligible for intensive chemotherapy } \\
\text { with } 2: 1 \text { randomization } \\
\text { sAML: } 41 \% \text { vs. } 34 \%\end{array}$ & $\begin{array}{c}76(36-93) \\
\text { Venetoclax arm: } \\
76 \text { (36-93) } \\
\text { Placebo arm:76 (41-88) }\end{array}$ & $\begin{array}{l}\text { LDAC } 20 \mathrm{mg} \text { BID for } 10 \text { days + } \\
\text { Venetoclax } 600 \mathrm{mg} \text { PO daily } \\
\text { every } 28 \text {-day cycle vs. LDAC } 20 \\
\text { mg BID for } 10 \text { days + Placebo }\end{array}$ & $\begin{array}{c}\text { CR + CRi: } \\
48 \% \text { vs. } 13 \% \\
(p<0.001) \\
\text { CR + CRh: } \\
47 \% \text { vs. } 15 \% \\
(p<0.001) \\
\text { CR: } 27 \% \text { vs. } 7 \%(p<0.001)\end{array}$ & $\begin{array}{l}\text { Median EFS: } \\
4.7 \text { mo vs. } 2.0 \text { mo } \\
(p=0.002)\end{array}$ & $\begin{array}{c}\text { Pre-planned Median OS } \\
\text { analysis: } \\
7.2 \text { mo vs. } 4.1 \text { mo } \\
\text { HR } 0.67 \text { [0.47-0.96] ( } p=0.03) \\
\text { Additional 6-mo follow-up } \\
\text { Median OS analysis: } 8.4 \text { mo vs. } \\
4.1 \text { mo } \\
\text { HR } 0.70[0.50-0.99](p=0.04)\end{array}$ \\
\hline Scappaticci et al. [84] & $\begin{array}{l}\text { Retrospective case-control study, adult } \\
\text { patients ( } \geq 60 \text { years old) with newly } \\
\text { diagnosed AML who were ineligible } \\
\text { for standard induction chemotherapy }\end{array}$ & $\begin{array}{l}\text { Clofarabine: } \\
72.7(60.7-80.9) \\
\text { FLAG: } \\
70.2(60.1-83.0)\end{array}$ & Clofarabine vs. FLAG & 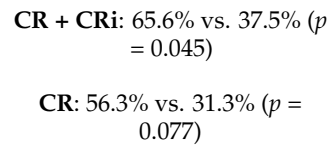 & $\begin{array}{c}\text { Median EFS: } 7.0 \text { mo vs. } 2.8 \\
\operatorname{mo}(p=0.110)\end{array}$ & $\begin{array}{l}\text { Median OS: } 7.9 \text { mo vs. } 2.8 \mathrm{mo} \\
\qquad(p=0.085)\end{array}$ \\
\hline
\end{tabular}




\subsubsection{Venetoclax +/- LDAC}

Venetoclax has also been evaluated as a monotherapy ( $800 \mathrm{mg}$ daily) in patients with relapsed/refractory disease or those who are unfit for intensive chemotherapy. In a phase 2 study of 32 patients (median age 71 years) with $94 \%$ having received prior therapy (including $75 \%$ receiving prior HMA), the CR/CRi rates were $19 \%$ with a median leukemia-free survival (LFS) of 2.3 months, median OS of 4.7 months, and more favorable results in IDH-mutated AML [85]. The combination of venetoclax and LDAC was granted accelerated approval by FDA in 2018 based on the results of the phase $1 \mathrm{~b} / 2$ study reporting a $44 \%$ CR/CRi rate and median OS of 10.1 months [82].

This led to the VIALE-C trial, a phase 3, 2:1 randomized trial comparing LDAC and placebo with LDAC and venetoclax (600 mg daily dose). Unfortunately, LDAC and venetoclax did not result in a significant improvement in the median OS (7.2 months vs. 4.1 months, $p=0.11$ ) at the time of pre-planned analysis; however, with an unplanned additional 6-months of follow-up, significant improvement in the median OS was seen with the combination (8.4 months vs. 4.1 months, $p=0.04$ ) [83]. The combination also resulted in higher CR/CRi rates, including a $27 \% \mathrm{CR}$ rate, compared with LDAC monotherapy $(48 \%$ vs. $13 \%, p<0.001)$ [83].

\subsection{3. $\mathrm{GO}+/-\mathrm{HMA}$}

Gemtuzumab ozogamicin (GO), is a CD33-monoclonal antibody combined with calcheamicin (DNA intercalator), which was first approved in 2000 for the treatment of relapsed/refractory AML in unfit patients. It has had a tumultuous history, particularly in elderly patients [86]. Following its approval, it was studied in combination with azacitidine. In a pilot study by Nand et al., azacitidine, GO, and hydroxyurea resulted in a $40 \%$ CR/CRi rate with a median survival of 10 months in an elderly patient population (median age 76 years) [69]. A phase 2 study published in 2013 reported on the combination of azacitidine and GO and noted a CR/CRi rate of $44 \%$ in its favorable-risk cohort (median age 71 years) and $35 \%$ in its adverse-risk cohort (median age 75 years) [70].

Furthermore, the median RFS was 8 months in the favorable-risk cohort and 7 months in the adverse-risk cohort, with an OS of 11 months in both groups [70]. The EORTCGIMEMA AML-19 trial was a phase 3 study comparing BSC to GO in patients over 60 years old with newly diagnosed AML who were unfit for intensive chemotherapy. GO was found to improve the median OS compared with BSC (4.9 months vs. 3.6 months, $p=0.005$ ) [81]. GO monotherapy could be considered in patients who are not fit to tolerate HMA or LDAC combinations discussed above.

Clofarabine, a nucleoside analog, has been studied retrospectively in older patients ineligible for induction chemotherapy with promising results [84].

\section{Consolidation Treatment}

While most patients treated with induction chemotherapy have a complete remission, durability following treatment was an early issue with intensive therapy until postremission, or consolidation, treatments were studied and found to be beneficial in sustaining these responses and potentially resulting in long-term cure. Consolidation is often achieved with either chemotherapy alone or with chemotherapy followed by hematopoietic stem cell transplantation.

\subsection{Chemotherapy}

Post-remission chemotherapy, namely with the use of varying doses of cytarabine was initially utilized following small, uncontrolled studies in the early 1980s and was solidified as a mainstay for post-remission therapy following intensive induction since the publication of CALGB-8525 in 1994. However, the optimal dose, cycles, and timing of cytarabine administration are not entirely clear. Furthermore, many of these studies were performed in younger patients while the benefits in older, yet "fit" patients is somewhat murkier. While CALGB-8525 (Table 4) did include a large number of patients over 60 years 
old, only $29 \%$ were able to complete the four courses of high-dose cytarabine (HIDAC), at a dose of $3 \mathrm{~g} / \mathrm{m}^{2}$, compared with $66 \%$ completing courses of $400 \mathrm{mg} / \mathrm{m}^{2}$ continuous infusion cytarabine [23].

While HIDAC resulted in prolonged survival in the entire studied cohort and subgroup of patients under 60 years old, it did not improve survival in those over 60 years old [23]. Later analyses of this study also found that patients with a normal karyotype, core-binding factor (CBF), and those with RAS-mutated, non-CBF AML had a lower incidence of relapse with HIDAC $[87,88]$. A lower dose $\left(2 \mathrm{~g} / \mathrm{m}^{2}\right)$ was evaluated via a single institution study without a comparator arm in older patients with good tolerability [89]. Furthermore, a modified intermediate-dose cytarabine (IDAC, $1 \mathrm{~g} / \mathrm{m}^{2}$ every $12 \mathrm{~h}$ for 5 days) was compared to HIDAC as part of a multiagent treatment regimen in Japan and resulted in similar outcomes and less hematologic toxicity [90].

However, given the complexity of the treatment schedule and multiagent approach, it is difficult to extrapolate these results to patients receiving single-agent cytarabine as a consolidation treatment. An alternative dosing schedule HIDAC has shown promise in young patients with quicker hematologic recovery, less days in the hospital, lower infection rates and no difference in survival with or without co-administration of pegfilgrastim compared with standard HIDAC dosing [91]. Further evaluation in additional randomized trials amongst older patients is needed. Notably patients treated with HMA and venetoclax do not typically undergo consolidation chemotherapy and instead remain on HMA/venetoclax as long as the response continues or toxicities are not seen. 
Table 4. Consolidation regimens for adults with AML with an emphasis on older adults.

\begin{tabular}{|c|c|c|c|c|c|c|}
\hline Study/Author & Phase/Population & Median Age (Years) [Range] & Medications & $\mathrm{CR}+\mathrm{CRi} / \mathrm{CR}$ & DFS/EFS/PFS/RFS & os \\
\hline CALGB-8525; Mayer et al. [10] & $\begin{array}{l}\text { III, } 1088 \text { patients ( } \geq 16 \text { years } \\
\text { old) with newly diagnosed } \\
\text { primary AML who received } \\
\text { intensive induction } \\
\text { chemotherapy } \\
596 \text { adult patients in CR went } \\
\text { on to be randomized to one of } \\
\text { three post-remission cytarabine } \\
\text { doses }\end{array}$ & $\begin{array}{c}52(16-86) \\
32 \% \text { patients were }>60\end{array}$ & $\begin{array}{l}\text { All patients received induction } \\
\text { with } 7 \text {-days of continuous } \\
\text { cytarabine } 200 \mathrm{mg} / \mathrm{m}^{2} \text { infusion } \\
\text { and } 3 \text {-days of bolus } \\
\text { daunorubicin } 45 \mathrm{mg} / \mathrm{m}^{2} \text { for } \\
\leq 60 \text { years old and } 30 \mathrm{mg} / \mathrm{m}^{2} \\
\text { for }>60 \text { years old) } \\
\text { Patients in CR after induction } \\
\text { were randomized to one of } \\
\text { three Cytarabine regimens } \\
\text { (four 28-day cycles): } \\
\text { (1) } 100 \mathrm{mg} / \mathrm{m}^{2} \text { continuous } \\
\text { infusion for } 5 \text { days } \\
\text { (2) } 400 \mathrm{mg} / \mathrm{m}^{2} \text { continuous } \\
\text { infusion for } 5 \text { days } \\
\text { (3) } 3 \mathrm{~g} / \mathrm{m}^{2} \text { over } 3 \mathrm{~h} \text { q12h on } \\
\text { days } 1,3,5\end{array}$ & $\begin{array}{c}\frac{\text { After Induction }}{\text { CR }} \\
<40 \text { yrs: } 75 \% \\
40-60 \text { yrs: } \\
68>60 \text { yrs: } 47 \%\end{array}$ & $\begin{array}{l}\text { 4-yr DFS (pts who received } \\
\text { consolidation) } \\
\text { All: } 21 \% \text { vs. } 25 \% \text { vs. } 39 \%(p= \\
0.003) \\
\text { Stratified by age } \\
<40 \text { yrs: } 32 \% \\
40-60 \text { yrs: } 29 \% \\
>60 \text { yrs: } 14 \% \\
\text { ( } p<0.001) \\
\text { Over } 60 \text { yrs }(n=129): \\
16 \% \text { or less for all three doses }(p \\
=0.19)\end{array}$ & 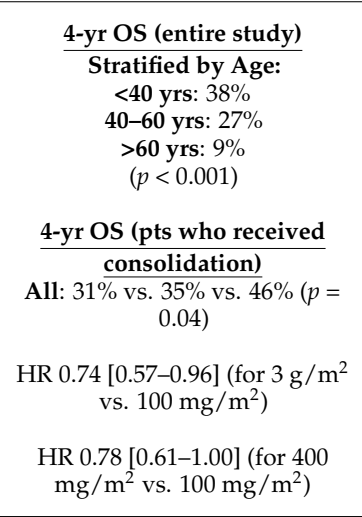 \\
\hline Sperr et al. [67] & $\begin{array}{c}79 \text { adult patients ( } \geq 60 \text { years } \\
\text { old) with de novo AML of } \\
\text { whom } 49 \text { patients had CR } \\
\text { following intensive induction } \\
\text { chemotherapy at a single } \\
\text { institution }\end{array}$ & $70(60-89)$ & $\begin{array}{c}\text { Cytarabine } 2 \mathrm{~g} / \mathrm{m}^{2} \text { over } 3 \mathrm{~h} \mathrm{q} 12 \\
\mathrm{~h} \text { on days } 1,3,5 \text { every } 28 \text {-days } \\
\text { for } 4 \text { cycles }\end{array}$ & $\begin{array}{c}\text { CR (after induction) } 62 \% \\
\text { Median Continuous CR (CCR) } \\
15.9 \text { mo } \\
5 \text {-yr CCR } 30 \%\end{array}$ & $\begin{array}{l}\text { Median DFS } \\
\quad 15.5 \mathrm{mo} \\
\text { 5-yr DFS 22\% }\end{array}$ & $\begin{array}{c}\text { Median OS (all pts) } 10.6 \mathrm{mo} \\
\text { 5-yr OS (all pts) } 18 \% \\
\text { Median OS (consolidation pts) } \\
31.8 \text { mo } \\
\text { 5-yr OS (consolidation pts) } \\
34 \%\end{array}$ \\
\hline Fukushima et al. [75] & $\begin{array}{l}26 \text { adult patients ( } \geq 18 \text { years } \\
\text { old) with newly diagnosed } \\
\text { AML } \\
21 \text { of these patients were } \\
\text { randomized to HIDAC or } \\
\text { modified IDAC (mIDAC) }\end{array}$ & $\begin{array}{l}\text { HIDAC Arm } \\
48(26-43) \\
\text { mIDAC Arm } \\
50(20-64)\end{array}$ & $\begin{array}{c}\text { Multiagent chemotherapy } \\
\text { including remission-induction, } \\
\text { consolidation, and } \\
\text { intensification regimens } \\
\text { containing two cycles of either: } \\
\text { HIDAC } 2 \mathrm{~g} / \mathrm{m}^{2} \mathrm{q} 12 \mathrm{~h} \text { on days } \\
1-5 \text { or } \\
\text { mIDAC } 1 \mathrm{~g} / \mathrm{m}^{2} \mathrm{q} 12 \mathrm{~h} \text { on days } \\
1-5\end{array}$ & CR $84.6 \%$ & $\begin{array}{c}4 \text {-yr RFS } \\
49 \% \text { vs. } 56 \%(p=0.86)\end{array}$ & Not reported \\
\hline $\begin{array}{c}\text { AMLSG 07-04; } \\
\text { Jaramillo et al. [68] }\end{array}$ & $\begin{array}{l}\text { II/III, } 568 \text { adult patients (18-60 } \\
\text { years old) with newly } \\
\text { diagnosed AML in CR cohorts } \\
\text { after induction with ICE } \\
\text { chemotherapy } \pm \text { ATRA }\end{array}$ & $\begin{array}{c}\text { German Intergroup Arm } \\
41.6 \text { (19-60) } \\
\text { HIDAC 123 Arm } \\
47.7(18-61) \\
\text { HIDAC 135 Arm } \\
47.6(18-61)\end{array}$ & $\begin{array}{c}\text { HIDAC } 3 \mathrm{~g} / \mathrm{m}^{2} \mathrm{q} 12 \mathrm{~h} \text { on days } \\
1-3 \text { with pegfilgrastim vs. days } \\
1,3,5 \text { with or without } \\
\text { pegfilgrastim (Standard } \\
\text { German Intergroup Arm) }\end{array}$ & Not applicable & $\begin{array}{c}\text { 2-yr RFS } \\
50 \% \text { vs. } 51 \% \\
4 \text {-yr RFS } \\
41 \% \text { vs. } 46 \% \\
\text { 6-yr RFS } \\
40 \% \text { vs. } 44 \% \\
(p=0.48)\end{array}$ & $\begin{array}{c}\text { 2-yr OS } \\
75 \% \text { vs. } 74 \% \\
\text { 4-yr OS62\% vs. } 64 \% \\
6 \text {-yr OS } \\
60 \% \text { vs. } 59 \% \\
(p=0.90)\end{array}$ \\
\hline
\end{tabular}




\subsection{Hematopoietic Stem Cell Transplantation}

Hematopoietic stem cell transplantation, including both allogeneic (allo-SCT) and autologous stem cell transplantation (ASCT), remains a potentially curative option for fit, older patients. Since 2000, there have been growing numbers of older patients undergoing allo-SCT [92]. Survival has also improved with allo-SCT, although inferior outcomes were seen with myeloablative conditioning [92]. Age does not have a negative influence on transplant outcomes [93-95]. Much of the data on allo-SCT in elderly patients is from retrospective or small, early-phase studies evaluating everything from the intensity of conditioning regimens to stem cell sources and donor-recipient characteristics [96-104].

Reduced-intensity conditioning provides an avenue for allo-SCT in older patients with lower TRM and LFS, higher relapse rates, and similar overall survival [104,105]. Allo-SCT with a HLA-matched donor, particularly from a sibling donor, appears to be a more effective consolidation method than autologous stem cell transplantation (autoSCT) [106-108]. Although relapses are more common with auto-SCT, it is associated with lower treatment-related mortality and similar overall survival [106-109]. Auto-SCT remains a safe and effective consolidation approach in some older AML patients who do not have a readily available donor $[110,111]$.

\section{Maintenance Treatment}

Since many patients are unable to safely undergo curative intent treatment, and even those who can endure these initial treatments, they are often unable to undergo further intensive therapies in the event of relapse. Thus, effective and tolerable post-remission maintenance treatments are paramount in improving the survival and remission for these patients. Several approaches have been studied, with and without stem cell transplantation. The use of hypomethylating agents has shown promise in this space. HOVON-97 evaluated the role of subcutaneous azacitidine $\left(50 \mathrm{mg} / \mathrm{m}^{2}\right.$ on days $1-5$ of 28 -day cycle for 12 cycles) as maintenance therapy following at least two cycles of intensive chemotherapy for AML in older patients (Table 5) [112].

Although azacitidine maintenance did not improve the OS it did improve the DFS [112]. Unfortunately, when azacitidine was studied in patients as a maintenance treatment after receiving allogeneic stem cell transplantation, it did not result in improved RFS or OS [113]. More recently, QUAZAR AML-001 studied the use of oral azacitidine (CC-486 $300 \mathrm{mg}$ daily for days 1-14 of 28-day cycle) as a maintenance treatment for older patients in first remission after intensive treatment [114]. CC-486 improved not only the RFS but also the OS without detrimental effects on quality of life [114]. Given the durable benefits of therapies affecting the immune system, such as allogeneic stem cell transplantation, there has been hope regarding the role of immune checkpoint inhibitors.

An early phase study of nivolumab maintenance in patients with high-risk AML who were not undergoing allogeneic stem cell transplantation showed an RFS comparable to historical observations but a promising OS, thus, prompting evaluation as part of combination therapy for patients with high-risk AML [115]. Optimal maintenance strategies need to be determined for older patients who are limited in their ability to receive intensive treatments upon relapse of their disease.

Table 5. AML maintenance regimens with an emphasis on older adult outcomes.

\begin{tabular}{|c|c|c|c|c|c|}
\hline Study/Author & Phase/Population & $\begin{array}{l}\text { Median Age (Years) } \\
\text { [Range] }\end{array}$ & Medications & DFS/EFS/PFS/RFS & OS \\
\hline $\begin{array}{c}\text { HOVON97; } \\
\text { Huls et al. [112] }\end{array}$ & $\begin{array}{c}\text { III, } 116 \text { adult patients }(\geq 60 \\
\text { years old) with newly } \\
\text { diagnosed AML or MDS-RAEB } \\
\text { in CR/CRi after at least } 2 \\
\text { cycles of intensive } \\
\text { chemotherapy }\end{array}$ & $69(60-81)$ & $\begin{array}{c}5 \text {-AZA SC } 50 \mathrm{mg} / \mathrm{m}^{2} \text { on } \\
\text { days } 1-5 \text { of } 28 \text {-day cycle } \\
\text { (max } 12 \text { cycles) vs. } \\
\text { observation }\end{array}$ & $\begin{array}{c}\text { Median DFS } \\
15.9 \text { mo vs. } 10.3 \text { mo } \\
\text { HR } 0.62[0.41-0.95](p= \\
0.026) \\
\text { 12-mo DFS } \\
64 \% \text { vs. } 42 \%(p=0.04)\end{array}$ & $\begin{array}{c}\text { 12-mo OS } \\
84 \% \text { vs. } 70 \%(p=0.69) \\
\text { HR } 0.91[0.58-1.44](p \\
=0.69)\end{array}$ \\
\hline $\begin{array}{l}\text { QUAZAR AML-001; } \\
\text { Wei et al. [114] }\end{array}$ & $\begin{array}{c}\text { III, } 472 \text { adult patients ( } \geq 55 \\
\text { years old) with AML in } \\
\text { CR/CRi after induction } \\
\text { chemotherapy with or without } \\
\text { consolidation and were not } \\
\text { being evaluated for allo-SCT }\end{array}$ & $68(55-86)$ & $\begin{array}{l}\text { CC-486 (oral form of } \\
\text { azacitidine) } 300 \mathrm{mg} \text { PO } \\
\text { vs. placebo PO daily for } \\
\text { days 1-14 of 28-day } \\
\text { cycle }\end{array}$ & $\begin{array}{c}\text { Median RFS } \\
10.2 \text { mo vs. } 4.8 \text { mo }(p< \\
0.001)\end{array}$ & $\begin{array}{c}\text { Median OS } \\
24.7 \text { mo vs. } 14.8 \text { mo }(p \\
<0.001)\end{array}$ \\
\hline
\end{tabular}


Table 5. Cont.

\begin{tabular}{|c|c|c|c|c|c|}
\hline Study/Author & Phase/Population & $\begin{array}{l}\text { Median Age (Years) } \\
\text { [Range] }\end{array}$ & Medications & DFS/EFS/PFS/RFS & OS \\
\hline $\begin{array}{l}\text { NCT00887068; } \\
\text { Oran et al. [113] }\end{array}$ & $\begin{array}{c}\text { I/II, } 187 \text { adult patients (18-75 } \\
\text { years old) with AML/MDS in } \\
\text { CR with "high-risk features" } \\
\text { between } 42-100 \text { days after } \\
\text { allo-SCT }\end{array}$ & $\begin{array}{l}\text { AZA arm: } \\
57(19-72) \\
\text { Obs arm: } \\
57.5(20-75)\end{array}$ & $\begin{array}{l}\text { SC } 5 \text {-AZA } 32 \mathrm{mg} / \mathrm{m}^{2} \text { on } \\
\text { days } 1-5 \text { vs. of } 28 \text {-day } \\
\text { cycle (max } 12 \text { cycles) vs. } \\
\text { observation }\end{array}$ & $\begin{array}{c}\text { Median RFS } \\
2.07 \text { yr vs. } 1.28 \text { yr } \\
(p=0.43) \\
\text { HR } 0.73[0.49-1.1](p= \\
0.14)\end{array}$ & $\begin{array}{c}\text { Median OS } \\
2.52 \text { yr vs. 2.56 yr } \\
(p=0.85) \\
\text { HR 0.84 [0.55-1.29] ( } p \\
=0.43)\end{array}$ \\
\hline Reville et al. [115] & $\begin{array}{l}\text { II, } 15 \text { adult patients ( } \geq 18 \text { years } \\
\text { old) with "high-risk" AML in } \\
\text { CR/CRi/PR who were not } \\
\text { being considered for allo-SCT }\end{array}$ & $56(31-71)$ & $\begin{array}{l}\text { Nivolumab } 3 \mathrm{mg} / \mathrm{kg} \text { IV } \\
\text { q2w for } 6 \text { cycles then } \\
\text { q4w for cycles } 7-12 \text {, } \\
\text { then q3mo after cycle } 12\end{array}$ & $\begin{array}{c}\text { Median RFS } 8.48 \text { mo } \\
\text { 6-mo RFS } 57.1 \%\end{array}$ & $\begin{array}{l}\text { Median OS Not } \\
\text { reached }\end{array}$ \\
\hline
\end{tabular}

\section{Measurable Residual Disease (MRD)}

Measurable (previously minimal) residual disease has been a developing area of study over the last decade with significant clinical implications, and its assessment after completion of intensive therapy has even been included in recent guidelines $[1,116]$. Given the potential for sampling error or variation in bone marrow evaluation for morphologic evidence of persistent leukemia during or after treatment, more sensitive approaches were developed and studied [117]. The ability to detect the presence of minute numbers of cells (at least 1:10,000 and even 1:100,000) by one of three methods, multiparameter flow cytometry (MFC), next-generation sequencing (NGS), or reverse-transcriptase quantitative polymerase chain reaction (RT-qPCR) has been found to be prognostic and in other diseases (such as ALL) prompts initiation of specific alternate therapies [118-123].

Cytotoxic, targeted, and cellular therapies can lead to alterations and evolution in the molecular and genomic characteristics of any residual disease, emphasizing the importance of inclusion of NGS testing at some interval after these treatments to potentially guide future treatment options $[124,125]$. Additional studies are assessing combinations of these methods at various time points in the disease course and with different samples (peripheral blood vs. bone marrow) $[126,127]$.

\section{Supportive Care}

The treatment of elderly patients with AML is fraught with difficulties for the patient, caregivers and providers. Palliative and supportive care have been shown to play a significant role in the optimal management of patients with malignancies; however, several barriers are thought to exist regarding its integration into the management of hematologic malignancies [128].

\section{Role of Integrated Palliative Care}

Palliative care in hematologic malignancies is paramount for maintaining quality of life (QOL) and tolerating treatment, emotional stress, managing toxicities, and for survivorship in the elderly [129]. However, palliative care clinicians may lack adherence to quality measures in symptom assessment and meeting the emotional needs in patients with hematologic malignancies, compared to those with solid tumors [130]. Palliative care support is on the rise over the last decade in hematologic malignancies [131]. When integrated into the care of a patient with AML, palliative care improves QOL and decreases depression as well as post-traumatic stress disorder (PTSD) symptoms with effects lasting more than 6 months [132]. Yet early palliative care ( $>30$ days prior to death) is often still lacking, with a median time from first palliative care encounter to death of 10 days [131].

\section{Future Directions}

AML is often a disease of older adults in the United States, many of which have multiple medical comorbidities and are often able to tolerate limited, if any, intensive therapy. There are a number of novel approaches currently being investigated, ranging from small molecule inhibitors, targeted agents, and cellular therapies targeted at engaging the immune system to destroy previously veiled leukemic cells. Uproleselan (GMI-1271), a 
novel E-selectin antagonist, is perhaps the furthest along in the drug development pathway and is currently under phase 3 evaluation in both frontline and relapsed/refractory AML in combination with chemotherapy $[133,134]$.

With the prevalence and poor outcomes of TP53-mutated AML, targeting p53 has been of paramount importance in AML. Eprenetapopt (APR-246), a novel intravenous infusion that causes p53 re-conformation, in turn reactivating its cell cycle arrest and proapoptotic functions is currently being studied in combination with azacitidine with promise in early studies $[135,136]$. There are a number of different approaches being studied that aim to enhance host immune response with either bispecific antibodies, or cellular therapies, namely chimeric antigen receptor T-cells (CAR-T) or donor leukocyte infusion (DLI) [137-147]. Current bispecific constructs that are in various stages of evaluation include CD3-FLT3, CD3-CD33, and CD3-CD123 [143-147].

Some current targets for CAR-T therapy include CD13 and TIM3, CD33, CD34, CD38, CD56, CD70, CLL1, CD117, and CD123 [138-142]. We remain hopeful that, over the next few years, continued advancement in the understanding of the biology of AML and an emphasis on development of precision medicine approaches will produce effective, tolerable, and potentially curative approaches for patients unable to undergo treatment with intensive therapies.

\section{Conclusions}

AML is a heterogenous clonal disorder that hijacks normal hematopoiesis in order to promote its own malignant survival. The incidence of AML increases with advancing age with the bulk of patients who develop AML being 60 years of age or older. Historically these older AML patients have been treated like their younger counterparts with high intensity induction chemotherapy. The biology of AML in older adults, however, is not like in younger patients due to an enrichment for adverse risk cytogenetic and molecular mutations, namely monosomal karyotypes, complex cytogenetics, ASXL1 mutations, and p53 mutations, which confer inherent resistance to traditional cytotoxic chemotherapy. Advancing age also brings with it additional medical co-morbidities and varying levels of fitness that must be taken into account prior to the initiation of therapy.

Fitness, with some caveats, such as $p 53$ mutations, continues to be the main determining factor in patient selection for intensive induction chemotherapy. Patients with core binding factor leukemia and NPM1 mutations with normal karyotypes should also be considered for induction chemotherapy given the curative potential. Most older AML patients, however, will not have favorable genetic risk. Fortunately, new therapies, such as hypomethylators and venetoclax, have arisen that confer morphologic remission and survival rates equal to or better than those of intensive chemotherapy.

These treatments can be given as outpatient therapy, do not have the same level of toxicities as intensive chemotherapy, and are tolerated with dose attenuation across the age spectrum of older adults with AML. Additional targeted therapies are in development to precisely block mutational pathways that are essential to leukemic cell survival. Additional work is required to improve the initial response rates for all older AML subgroups. Better consolidative/maintenance strategies that focus on MRD endpoints to lessen the time in therapy and to improve the overall survival are still sought underscoring the ongoing trials and tribulations of frontline therapy in older AML.

Author Contributions: A.S.Z. and J.L.R. reviewed the literature, wrote the manuscript, have read and agreed to the published version of the manuscript.

Funding: No direct funding contributed to this manuscript.

Institutional Review Board Statement: Not applicable.

Informed Consent Statement: Not applicable.

Data Availability Statement: Not applicable.

Conflicts of Interest: The authors report no conflict of interest. 


\section{References}

1. NCCN. Clinical Practice Guidelines in Oncology (NCCN Guidelines): Acute Myeloid Leukemia; National Comprehensive Cancer Network: Fort Washington, PA, USA, 2021.

2. Sekeres, M.A.; Guyatt, G.; Abel, G.; Alibhai, S.; Altman, J.K.; Buckstein, R.; Choe, H.; Desai, P.; Erba, H.; Hourigan, C.S.; et al. American Society of Hematology 2020 guidelines for treating newly diagnosed acute myeloid leukemia in older adults. Blood Adv. 2020, 4, 3528-3549. [CrossRef]

3. Pinto, A.; Zagonel, V.; Ferrara, F. Acute myeloid leukemia in the elderly: Biology and therapeutic strategies. Crit. Rev. Oncol./Hematol. 2001, 39, 275-287. [CrossRef]

4. Suarez, L.; Vidriales, M.B.; Moreno, M.J.; Lopez, A.; Garcia-Larana, J.; Perez-Lopez, C.; Tormo, M.; Lavilla, E.; Lopez-Berges, M.C.; Santiago, M.D.; et al. Differences in anti-apoptotic and multidrug resistance phenotypes in elderly and young acute myeloid leukemia patients are related to the maturation of blast cells. Haematologica 2005, 90, 54-59. [PubMed]

5. Godwin, J.E.; Kopecky, K.J.; Head, D.R.; Willman, C.L.; Leith, C.P.; Hynes, H.E.; Balcerzak, S.P.; Appelbaum, F.R. A Double-Blind Placebo-Controlled Trial of Granulocyte Colony-Stimulating Factor in Elderly Patients with Previously Untreated Acute Myeloid Leukemia: A Southwest Oncology Group Study (9031). Blood 1998, 91, 3607-3615. [CrossRef] [PubMed]

6. $\quad$ Farag, S.S.; Archer, K.J.; Mrózek, K.; Ruppert, A.S.; Carroll, A.J.; Vardiman, J.W.; Pettenati, M.J.; Baer, M.R.; Qumsiyeh, M.B.; Koduru, P.R.; et al. Pretreatment cytogenetics add to other prognostic factors predicting complete remission and long-term outcome in patients 60 years of age or older with acute myeloid leukemia: Results from Cancer and Leukemia Group B 8461. Blood 2006, 108, 63-73. [CrossRef] [PubMed]

7. Frohling, S.; Schlenk, R.F.; Kayser, S.; Morhardt, M.; Benner, A.; Dohner, K.; Dohner, H.; for the German-Austrian AML Study Group. Cytogenetics and age are major determinants of outcome in intensively treated acute myeloid leukemia patients older than 60 years: Results from AMLSG trial AML HD98-B. Blood 2006, 108, 3280-3288. [CrossRef] [PubMed]

8. Prassek, V.V.; Rothenberg-Thurley, M.; Sauerland, M.C.; Herold, T.; Janke, H.; Ksienzyk, B.; Konstandin, N.P.; Goerlich, D.; Krug, U.; Faldum, A.; et al. Genetics of acute myeloid leukemia in the elderly: Mutation spectrum and clinical impact in intensively treated patients aged 75 years or older. Haematologica 2018, 103, 1853-1861. [CrossRef] [PubMed]

9. Paschka, P.; Schlenk, R.F.; Gaidzik, V.I.; Habdank, M.; Krönke, J.; Bullinger, L.; Späth, D.; Kayser, S.; Zucknick, M.; Götze, K.; et al. IDH1 and IDH2 mutations are frequent genetic alterations in acute myeloid leukemia and confer adverse prognosis in cytogenetically normal acute myeloid leukemia with NPM1 mutation without FLT3 internal tandem duplication. J. Clin. Oncol. 2010, 28, 3636-3643. [CrossRef] [PubMed]

10. Eisfeld, A.K.; Kohlschmidt, J.; Mrózek, K.; Blachly, J.S.; Walker, C.J.; Nicolet, D.; Orwick, S.; Maharry, S.E.; Carroll, A.J.; Stone, R.M.; et al. Mutation patterns identify adult patients with de novo acute myeloid leukemia aged 60 years or older who respond favorably to standard chemotherapy: An analysis of Alliance studies. Leukemia 2018, 32, 1338-1348. [CrossRef] [PubMed]

11. Juliusson, G.; Jädersten, M.; Deneberg, S.; Lehmann, S.; Möllgård, L.; Wennström, L.; Antunovic, P.; Cammenga, J.; Lorenz, F.; Ölander, E.; et al. The prognostic impact of FLT3-ITD and NPM1 mutation in adult AML is age-dependent in the population-based setting. Blood Adv. 2020, 4, 1094-1101. [CrossRef]

12. Ostronoff, F.; Othus, M.; Lazenby, M.; Estey, E.; Appelbaum, F.R.; Evans, A.; Godwin, J.; Gilkes, A.; Kopecky, K.J.; Burnett, A.; et al. Prognostic significance of NPM1 mutations in the absence of FLT3-internal tandem duplication in older patients with acute myeloid leukemia: A SWOG and UK National Cancer Research Institute/Medical Research Council report. J. Clin. Oncol. 2015, 33, 1157-1164. [CrossRef]

13. Döhner, H.; Estey, E.; Grimwade, D.; Amadori, S.; Appelbaum, F.R.; Büchner, T.; Dombret, H.; Ebert, B.L.; Fenaux, P.; Larson, R.A.; et al. Diagnosis and management of AML in adults: 2017 ELN recommendations from an international expert panel. Blood 2017, 129, 424-447. [CrossRef] [PubMed]

14. Østgård, L.S.G.; Medeiros, B.C.; Sengeløv, H.; Nørgaard, M.; Andersen, M.K.; Dufva, I.H.; Friis, L.S.; Kjeldsen, E.; Marcher, C.W.; Preiss, B.; et al. Epidemiology and Clinical Significance of Secondary and Therapy-Related Acute Myeloid Leukemia: A National Population-Based Cohort Study. J. Clin. Oncol. 2015, 33, 3641-3649. [CrossRef]

15. Hulegårdh, E.; Nilsson, C.; Lazarevic, V.; Garelius, H.; Antunovic, P.; Rangert Derolf, Å.; Möllgård, L.; Uggla, B.; Wennström, L.; Wahlin, A.; et al. Characterization and prognostic features of secondary acute myeloid leukemia in a population-based setting: A report from the Swedish Acute Leukemia Registry. Am. J. Hematol. 2015, 90, 208-214. [CrossRef]

16. Arber, D.A.; Orazi, A.; Hasserjian, R.; Thiele, J.; Borowitz, M.J.; Le Beau, M.M.; Bloomfield, C.D.; Cazzola, M.; Vardiman, J.W. The 2016 revision to the World Health Organization classification of myeloid neoplasms and acute leukemia. Blood 2016, 127, 2391-2405. [CrossRef]

17. Walter, M.J.; Shen, D.; Ding, L.; Shao, J.; Koboldt, D.C.; Chen, K.; Larson, D.E.; McLellan, M.D.; Dooling, D.; Abbott, R.; et al. Clonal Architecture of Secondary Acute Myeloid Leukemia. N. Engl. J. Med. 2012, 366, 1090-1098. [CrossRef]

18. Chen, X.; Othus, M.; Wood, B.L.; Walter, R.B.; Becker, P.S.; Percival, M.-E.; Abkowitz, J.L.; Appelbaum, F.R.; Estey, E.H. Comparison of myeloid blast counts and variant allele frequencies of gene mutations in myelodysplastic syndrome with excess blasts and secondary acute myeloid leukemia. Leuk. Lymphoma 2021, 62, 1226-1233. [CrossRef] [PubMed]

19. Dunbar, A.J.; Rampal, R.K.; Levine, R. Leukemia secondary to myeloproliferative neoplasms. Blood 2020, 136, 61-70. [CrossRef] [PubMed]

20. Menssen, A.J.; Walter, M.J. Genetics of progression from MDS to secondary leukemia. Blood 2020, 136, 50-60. [CrossRef] [PubMed] 
21. Rai, K.R.; Holland, J.F.; Glidewell, O.J.; Weinberg, V.; Brunner, K.; Obrecht, J.P.; Preisler, H.D.; Nawabi, I.W.; Prager, D.; Carey, R.W.; et al. Treatment of Acute Myelocytic Leukemia: A Study by Cancer and Leukemia Group, B. Blood 1981, 58, 1203-1212. [CrossRef]

22. Yates, J.; Glidewell, O.; Wiernik, P.; Cooper, M.; Steinberg, D.; Dosik, H.; Levy, R.; Hoagland, C.; Henry, P.; Gottlieb, A.; et al. Cytosine arabinoside with daunorubicin or adriamycin for therapy of acute myelocytic leukemia: A CALGB study. Blood 1982, 60, 454-462. [CrossRef] [PubMed]

23. Mayer, R.J.; Davis, R.B.; Schiffer, C.A.; Berg, D.T.; Powell, B.L.; Schulman, P.; Omura, G.A.; Moore, J.O.; McIntyre, O.R.; Frei, E. Intensive Postremission Chemotherapy in Adults with Acute Myeloid Leukemia. N. Engl. J. Med. 1994, 331, 896-903. [CrossRef]

24. Kuhlman, P.; Isom, S.; Pardee, T.S.; Burns, C.; Tawfik, B.; Lamar, Z.S.; Powell, B.L.; Klepin, H.D. Association between glycemic control, age, and outcomes among intensively treated patients with acute myeloid leukemia. Support. Care Cancer 2019, 27, 2877-2884. [CrossRef]

25. Löwenberg, B.; Ossenkoppele, G.J.; van Putten, W.; Schouten, H.C.; Graux, C.; Ferrant, A.; Sonneveld, P.; Maertens, J.; JongenLavrencic, M.; von Lilienfeld-Toal, M.; et al. High-Dose Daunorubicin in Older Patients with Acute Myeloid Leukemia. N. Engl. J. Med. 2009, 361, 1235-1248. [CrossRef]

26. Fernandez, H.F.; Sun, Z.; Yao, X.; Litzow, M.R.; Luger, S.M.; Paietta, E.M.; Racevskis, J.; Dewald, G.W.; Ketterling, R.P.; Bennett, J.M.; et al. Anthracycline Dose Intensification in Acute Myeloid Leukemia. N. Engl. J. Med. 2009, 361, 1249-1259. [CrossRef]

27. Thein, M.S.; Ershler, W.B.; Jemal, A.; Yates, J.W.; Baer, M.R. Outcome of older patients with acute myeloid leukemia. Cancer 2013, 119, 2720-2727. [CrossRef] [PubMed]

28. Elliot, K.; Tooze, J.A.; Geller, R.; Powell, B.L.; Pardee, T.S.; Ritchie, E.; Kennedy, L.; Callahan, K.E.; Klepin, H.D. The prognostic importance of polypharmacy in older adults treated for acute myelogenous leukemia (AML). Leuk. Res. 2014, 38, 1184-1190. [CrossRef]

29. Giles, F.J.; Borthakur, G.; Ravandi, F.; Faderl, S.; Verstovsek, S.; Thomas, D.; Wierda, W.; Ferrajoli, A.; Kornblau, S.; Pierce, S.; et al. The haematopoietic cell transplantation comorbidity index score is predictive of early death and survival in patients over 60 years of age receiving induction therapy for acute myeloid leukaemia. Br. J. Haematol. 2007, 136, 624-627. [CrossRef] [PubMed]

30. Ramjaun, A.; Nassif, M.O.; Krotneva, S.; Huang, A.R.; Meguerditchian, A.N. Improved targeting of cancer care for older patients: A systematic review of the utility of comprehensive geriatric assessment. J. Geriatr. Oncol. 2013, 4, 271-281. [CrossRef]

31. Takahashi, M.; Takahashi, M.; Komine, K.; Yamada, H.; Kasahara, Y.; Chikamatsu, S.; Okita, A.; Ito, S.; Ouchi, K.; Okada, Y.; et al. The G8 screening tool enhances prognostic value to ECOG performance status in elderly cancer patients: A retrospective, single institutional study. PLoS ONE 2017, 12, e0179694. [CrossRef]

32. Klepin, H.D.; Geiger, A.M.; Tooze, J.A.; Kritchevsky, S.B.; Williamson, J.D.; Ellis, L.R.; Levitan, D.; Pardee, T.S.; Isom, S.; Powell, B.L.; et al. The feasibility of inpatient geriatric assessment for older adults receiving induction chemotherapy for acute myelogenous leukemia. J. Am. Geriatr. Soc. 2011, 59, 1837-1846. [CrossRef]

33. Klepin, H.D.; Geiger, A.M.; Tooze, J.A.; Kritchevsky, S.B.; Williamson, J.D.; Pardee, T.S.; Ellis, L.R.; Powell, B.L. Geriatric assessment predicts survival for older adults receiving induction chemotherapy for acute myelogenous leukemia. Blood 2013, 121, 4287-4294. [CrossRef]

34. Hamaker, M.E.; Prins, M.C.; Stauder, R. The relevance of a geriatric assessment for elderly patients with a haematological malignancy-A systematic review. Leuk. Res. 2014, 38, 275-283. [CrossRef]

35. Deschler, B.; Ihorst, G.; Platzbecker, U.; Germing, U.; Marz, E.; de Figuerido, M.; Fritzsche, K.; Haas, P.; Salih, H.R.; Giagounidis, A.; et al. Parameters detected by geriatric and quality of life assessment in 195 older patients with myelodysplastic syndromes and acute myeloid leukemia are highly predictive for outcome. Haematologica 2013, 98, 208-216. [CrossRef] [PubMed]

36. Klepin, H.D.; Ritchie, E.; Major-Elechi, B.; Le-Rademacher, J.; Seisler, D.; Storrick, L.; Sanford, B.L.; Marcucci, G.; Zhao, W.; Geyer, S.A.; et al. Geriatric assessment among older adults receiving intensive therapy for acute myeloid leukemia: Report of CALGB 361006 (Alliance). J. Geriatr. Oncol. 2020, 11, 107-113. [CrossRef]

37. Saad, M.; Loh, K.P.; Tooze, J.A.; Pardee, T.S.; Ellis, L.R.; Powell, B.L.; Bhave, R.R.; Geiger, A.M.; Williamson, J.D.; Kritchevsky, S.; et al. Geriatric assessment and survival among older adults receiving postremission therapy for acute myeloid leukemia. Blood 2020, 136, 2715-2719. [CrossRef] [PubMed]

38. Scheepers, E.R.M.; Vondeling, A.M.; Thielen, N.; Griend, R.v.d.; Stauder, R.; Hamaker, M.E. Geriatric assessment in older patients with a hematologic malignancy: A systematic review. Haematologica 2020, 105, 1484-1493. [CrossRef] [PubMed]

39. Bhatt, V.R.; Wichman, C.; Al-Kadhimi, Z.S.; Koll, T.T.; Berger, A.; Armitage, J.O.; Holstein, S.A.; Gundabolu, K.; Maness, L.J. Integrating Geriatric Assessment and Genetic Profiling to Personalize Therapy Selection in Older Adults with Acute Myeloid Leukemia (AML). Blood 2019, 134, 120. [CrossRef]

40. Rowe, J.M.; Neuberg, D.; Friedenberg, W.; Bennett, J.M.; Paietta, E.; Makary, A.Z.; Liesveld, J.L.; Abboud, C.N.; Dewald, G.; Hayes, F.A.; et al. A phase 3 study of three induction regimens and of priming with GM-CSF in older adults with acute myeloid leukemia: A trial by the Eastern Cooperative Oncology Group. Blood 2004, 103, 479-485. [CrossRef]

41. Ohtake, S.; Miyawaki, S.; Fujita, H.; Kiyoi, H.; Shinagawa, K.; Usui, N.; Okumura, H.; Miyamura, K.; Nakaseko, C.; Miyazaki, Y.; et al. Randomized study of induction therapy comparing standard-dose idarubicin with high-dose daunorubicin in adult patients with previously untreated acute myeloid leukemia: The JALSG AML201 Study. Blood 2011, 117, 2358-2365. [CrossRef] 
42. Burnett, A.K.; Russell, N.H.; Hills, R.K.; Kell, J.; Cavenagh, J.; Kjeldsen, L.; McMullin, M.-F.; Cahalin, P.; Dennis, M.; Friis, L.; et al. A randomized comparison of daunorubicin $90 \mathrm{mg} / \mathrm{m} 2$ vs. $60 \mathrm{mg} / \mathrm{m} 2$ in AML induction: Results from the UK NCRI AML17 trial in 1206 patients. Blood 2015, 125, 3878-3885. [CrossRef] [PubMed]

43. Lee, J.-H.; Kim, H.; Joo, Y.-D.; Lee, W.-S.; Bae, S.H.; Zang, D.Y.; Kwon, J.; Kim, M.K.; Lee, J.; Lee, G.W.; et al. Prospective Randomized Comparison of Idarubicin and High-Dose Daunorubicin in Induction Chemotherapy for Newly Diagnosed Acute Myeloid Leukemia. J. Clin. Oncol. 2017, 35, 2754-2763. [CrossRef]

44. Pautas, C.; Merabet, F.; Thomas, X.; Raffoux, E.; Gardin, C.; Corm, S.; Bourhis, J.-H.; Reman, O.; Turlure, P.; Contentin, N.; et al. Randomized Study of Intensified Anthracycline Doses for Induction and Recombinant Interleukin-2 for Maintenance in Patients With Acute Myeloid Leukemia Age 50 to 70 Years: Results of the ALFA-9801 Study. J. Clin. Oncol. 2010, 28, 808-814. [CrossRef] [PubMed]

45. Castaigne, S.; Pautas, C.; Terré, C.; Raffoux, E.; Bordessoule, D.; Bastie, J.-N.; Legrand, O.; Thomas, X.; Turlure, P.; Reman, O.; et al. Effect of gemtuzumab ozogamicin on survival of adult patients with de-novo acute myeloid leukaemia (ALFA-0701): A randomised, open-label, phase 3 study. Lancet 2012, 379, 1508-1516. [CrossRef]

46. Hills, R.K.; Castaigne, S.; Appelbaum, F.R.; Delaunay, J.; Petersdorf, S.; Othus, M.; Estey, E.H.; Dombret, H.; Chevret, S.; Ifrah, N.; et al. Addition of gemtuzumab ozogamicin to induction chemotherapy in adult patients with acute myeloid leukaemia: A meta-analysis of individual patient data from randomised controlled trials. Lancet Oncol. 2014, 15, 986-996. [CrossRef]

47. Lambert, J.; Pautas, C.; Terré, C.; Raffoux, E.; Turlure, P.; Caillot, D.; Legrand, O.; Thomas, X.; Gardin, C.; Gogat-Marchant, K.; et al. Gemtuzumab ozogamicin for de novo acute myeloid leukemia: Final efficacy and safety updates from the open-label, phase III ALFA-0701 trial. Haematologica 2019, 104, 113-119. [CrossRef]

48. Stone, R.M.; Mandrekar, S.J.; Sanford, B.L.; Laumann, K.; Geyer, S.; Bloomfield, C.D.; Thiede, C.; Prior, T.W.; Döhner, K.; Marcucci, G.; et al. Midostaurin plus Chemotherapy for Acute Myeloid Leukemia with a FLT3 Mutation. N. Engl. J. Med. 2017, 377, 454-464. [CrossRef]

49. Lancet, J.E.; Cortes, J.E.; Hogge, D.E.; Tallman, M.S.; Kovacsovics, T.J.; Damon, L.E.; Komrokji, R.; Solomon, S.R.; Kolitz, J.E.; Cooper, M.; et al. Phase 2 trial of CPX-351, a fixed 5:1 molar ratio of cytarabine/daunorubicin, vs. cytarabine/daunorubicin in older adults with untreated AML. Blood 2014, 123, 3239-3246. [CrossRef]

50. Lancet, J.E.; Uy, G.L.; Cortes, J.E.; Newell, L.F.; Lin, T.L.; Ritchie, E.K.; Stuart, R.K.; Strickland, S.A.; Hogge, D.; Solomon, S.R.; et al. CPX-351 (cytarabine and daunorubicin) Liposome for Injection Versus Conventional Cytarabine Plus Daunorubicin in Older Patients With Newly Diagnosed Secondary Acute Myeloid Leukemia. J. Clin. Oncol. 2018, 36, 2684-2692. [CrossRef]

51. Benitez, L.L.; Perissinotti, A.J.; Rausch, C.R.; Klaus, J.; Clark, S.M.; Filtz, M.; Ratermann, K.; Treptow, C.; Griffin, S.; Olson, M.; et al. Multicenter comparison of high-dose cytarabine-based regimens versus liposomal daunorubicin and cytarabine (CPX-351) in patients with secondary acute myeloid leukemia. Leuk. Lymphoma 2021, 1-9. [CrossRef]

52. Vulaj, V.; Perissinotti, A.J.; Uebel, J.R.; Nachar, V.R.; Scappaticci, G.B.; Crouch, A.; Bixby, D.L.; Burke, P.W.; Maillard, I.; Talpaz, M.; et al. The FOSSIL Study: FLAG or standard 7+3 induction therapy in secondary acute myeloid leukemia. Leuk. Res. 2018, 70, 91-96. [CrossRef]

53. Lachowiez, C.; Konopleva, M.; Kadia, T.M.; Daver, N.; Loghavi, S.; Wang, S.A.; Adeoti, M.; Pierce, S.A.; Takahashi, K.; Short, N.J.; et al. Interim Analysis of the Phase 1b/2 Study of the BCL-2 Inhibitor Venetoclax in Combination with Standard Intensive AML Induction/Consolidation Therapy with FLAG-IDA in Patients with Newly Diagnosed or Relapsed/Refractory AML. Blood 2020, 136, 18-20. [CrossRef]

54. Kadia, T.M.; Borthakur, G.; Takahashi, K.; DiNardo, C.D.; Daver, N.; Pemmaraju, N.; Jabbour, E.; Jain, N.; Short, N.J.; Qiao, W.; et al. Phase II Study of CPX-351 Plus Venetoclax in Patients with Acute Myeloid Leukemia (AML). Blood 2020, 136, 20-22. [CrossRef]

55. Fenaux, P.; Mufti, G.J.; Hellström-Lindberg, E.; Santini, V.; Gattermann, N.; Germing, U.; Sanz, G.; List, A.F.; Gore, S.; Seymour, J.F.; et al. Azacitidine Prolongs Overall Survival Compared with Conventional Care Regimens in Elderly Patients with Low Bone Marrow Blast Count Acute Myeloid Leukemia. J. Clin. Oncol. 2010, 28, 562-569. [CrossRef] [PubMed]

56. Dombret, H.; Seymour, J.F.; Butrym, A.; Wierzbowska, A.; Selleslag, D.; Jang, J.H.; Kumar, R.; Cavenagh, J.; Schuh, A.C.; Candoni, A.; et al. International phase 3 study of azacitidine vs. conventional care regimens in older patients with newly diagnosed AML with $>30 \%$ blasts. Blood 2015, 126, 291-299. [CrossRef] [PubMed]

57. Döhner, H.; Dolnik, A.; Tang, L.; Seymour, J.F.; Minden, M.D.; Stone, R.M.; del Castillo, T.B.; Al-Ali, H.K.; Santini, V.; Vyas, P.; et al. Cytogenetics and gene mutations influence survival in older patients with acute myeloid leukemia treated with azacitidine or conventional care. Leukemia 2018, 32, 2546-2557. [CrossRef]

58. DiNardo, C.D.; Pratz, K.W.; Letai, A.; Jonas, B.A.; Wei, A.H.; Thirman, M.; Arellano, M.; Frattini, M.G.; Kantarjian, H.; Popovic, R.; et al. Safety and preliminary efficacy of venetoclax with decitabine or azacitidine in elderly patients with previously untreated acute myeloid leukaemia: A non-randomised, open-label, phase 1b study. Lancet Oncol. 2018, 19, 216-228. [CrossRef]

59. DiNardo, C.D.; Pratz, K.; Pullarkat, V.; Jonas, B.A.; Arellano, M.; Becker, P.S.; Frankfurt, O.; Konopleva, M.; Wei, A.H.; Kantarjian, H.M.; et al. Venetoclax combined with decitabine or azacitidine in treatment-naive, elderly patients with acute myeloid leukemia. Blood 2019, 133, 7-17. [CrossRef]

60. Pollyea, D.A.; Pratz, K.; Letai, A.; Jonas, B.A.; Wei, A.H.; Pullarkat, V.; Konopleva, M.; Thirman, M.J.; Arellano, M.; Becker, P.S.; et al. Venetoclax with azacitidine or decitabine in patients with newly diagnosed acute myeloid leukemia: Long term follow-up from a phase 1b study. Am. J. Hematol. 2021, 96, 208-217. [CrossRef] 
61. DiNardo, C.D.; Jonas, B.A.; Pullarkat, V.; Thirman, M.J.; Garcia, J.S.; Wei, A.H.; Konopleva, M.; Döhner, H.; Letai, A.; Fenaux, P.; et al. Azacitidine and Venetoclax in Previously Untreated Acute Myeloid Leukemia. N. Engl. J. Med. 2020, 383, 617-629. [CrossRef]

62. Kantarjian, H.M.; Thomas, X.G.; Dmoszynska, A.; Wierzbowska, A.; Mazur, G.; Mayer, J.; Gau, J.-P.; Chou, W.-C.; Buckstein, R.; Cermak, J.; et al. Multicenter, randomized, open-label, phase III trial of decitabine versus patient choice, with physician advice, of either supportive care or low-dose cytarabine for the treatment of older patients with newly diagnosed acute myeloid leukemia. J. Clin. Oncol. 2012, 30, 2670-2677. [CrossRef]

63. Maiti, A.; DiNardo, C.D.; Daver, N.G.; Rausch, C.R.; Ravandi, F.; Kadia, T.M.; Pemmaraju, N.; Borthakur, G.; Bose, P.; Issa, G.C.; et al. Triplet therapy with venetoclax, FLT3 inhibitor and decitabine for FLT3-mutated acute myeloid leukemia. Blood Cancer J. 2021, 11, 25. [CrossRef]

64. Blum, W.; Garzon, R.; Klisovic, R.B.; Schwind, S.; Walker, A.; Geyer, S.; Liu, S.; Havelange, V.; Becker, H.; Schaaf, L.; et al. Clinical response and miR-29b predictive significance in older AML patients treated with a 10-day schedule of decitabine. Proc. Natl. Acad. Sci. USA 2010, 107, 7473-7478. [CrossRef]

65. Ritchie, E.K.; Feldman, E.J.; Christos, P.J.; Rohan, S.D.; Lagassa, C.B.; Ippoliti, C.; Scandura, J.M.; Carlson, K.; Roboz, G.J. Decitabine in patients with newly diagnosed and relapsed acute myeloid leukemia. Leuk. Lymphoma 2013, 54, $2003-2007$. [CrossRef] [PubMed]

66. Welch, J.S.; Petti, A.A.; Miller, C.A.; Fronick, C.C.; O’Laughlin, M.; Fulton, R.S.; Wilson, R.K.; Baty, J.D.; Duncavage, E.J.; Tandon, B.; et al. TP53 and Decitabine in Acute Myeloid Leukemia and Myelodysplastic Syndromes. N. Engl. J. Med. 2016, 375, 2023-2036. [CrossRef] [PubMed]

67. DiNardo, C.D.; Maiti, A.; Rausch, C.R.; Pemmaraju, N.; Naqvi, K.; Daver, N.G.; Kadia, T.M.; Borthakur, G.; Ohanian, M.; Alvarado, Y.; et al. 10-day decitabine with venetoclax for newly diagnosed intensive chemotherapy ineligible, and relapsed or refractory acute myeloid leukaemia: A single-centre, phase 2 trial. Lancet Haematol. 2020, 7, e724-e736. [CrossRef]

68. Maiti, A.; Qiao, W.; Sasaki, K.; Ravandi, F.; Kadia, T.M.; Jabbour, E.J.; Daver, N.G.; Borthakur, G.; Garcia-Manero, G.; Pierce, S.A.; et al. Venetoclax with decitabine vs. intensive chemotherapy in acute myeloid leukemia: A propensity score matched analysis stratified by risk of treatment-related mortality. Am. J. Hematol. 2021, 96, 282-291. [CrossRef] [PubMed]

69. Nand, S.; Godwin, J.; Smith, S.; Barton, K.; Michaelis, L.; Alkan, S.; Veerappan, R.; Rychlik, K.; Germano, E.; Stiff, P. Hydroxyurea, azacitidine and gemtuzumab ozogamicin therapy in patients with previously untreated non-M3 acute myeloid leukemia and high-risk myelodysplastic syndromes in the elderly: Results from a pilot trial. Leuk. Lymphoma 2008, 49, 2141-2147. [CrossRef]

70. Nand, S.; Othus, M.; Godwin, J.E.; Willman, C.L.; Norwood, T.H.; Howard, D.S.; Coutre, S.E.; Erba, H.P.; Appelbaum, F.R. A phase 2 trial of azacitidine and gemtuzumab ozogamicin therapy in older patients with acute myeloid leukemia. Blood 2013, 122, 3432-3439. [CrossRef]

71. DiNardo, C.D.; Stein, A.S.; Stein, E.M.; Fathi, A.T.; Frankfurt, O.; Schuh, A.C.; Döhner, H.; Martinelli, G.; Patel, P.A.; Raffoux, E.; et al. Mutant Isocitrate Dehydrogenase 1 Inhibitor Ivosidenib in Combination with Azacitidine for Newly Diagnosed Acute Myeloid Leukemia. J. Clin. Oncol. 2021, 39, 57-65. [CrossRef]

72. DiNardo, C.D.; Schuh, A.C.; Stein, E.M.; Fernandez, P.M.; Wei, A.; De Botton, S.; Zeidan, A.M.; Fathi, A.T.; Quek, L.; Kantarjian, H.M.; et al. Enasidenib Plus Azacitidine Significantly Improves Complete Remission and Overall Response Compared with Azacitidine Alone in Patients with Newly Diagnosed Acute Myeloid Leukemia (AML) with Isocitrate Dehydrogenase 2 (IDH2) Mutations: Interim Phase II Results from an Ongoing, Randomized Study. Blood 2019, 134, 643. [CrossRef]

73. Dinardo, C.D.; Schuh, A.C.; Stein, E.M.; Montesinos, P.; Wei, A.; Botton, S.D.; Zeidan, A.M.; Fathi, A.T.; Quek, L.; Kantarjian, H.M.; et al. Effect of enasidenib (ENA) plus azacitidine (AZA) on complete remission and overall response versus AZA monotherapy in mutant-IDH2 (mIDH2) newly diagnosed acute myeloid leukemia (ND-AML). J. Clin. Oncol. 2020, 38, 7501. [CrossRef]

74. Wei, Y.; Cao, Y.; Sun, R.; Cheng, L.; Xiong, X.; Jin, X.; He, X.; Lu, W.; Zhao, M. Targeting Bcl-2 Proteins in Acute Myeloid Leukemia. Front. Oncol. 2020, 10, 2137. [CrossRef]

75. Maiti, A.; DiNardo, C.D.; Wang, S.A.; Jorgensen, J.; Kadia, T.M.; Daver, N.G.; Short, N.J.; Yilmaz, M.; Pemmaraju, N.; Borthakur, G.; et al. Prognostic value of measurable residual disease after venetoclax and decitabine in acute myeloid leukemia. Blood Adv. 2021, 5, 1876-1883. [CrossRef] [PubMed]

76. Abbas, S.; Lugthart, S.; Kavelaars, F.G.; Schelen, A.; Koenders, J.E.; Zeilemaker, A.; van Putten, W.J.L.; Rijneveld, A.W.; Löwenberg, B.; Valk, P.J.M. Acquired mutations in the genes encoding IDH1 and IDH2 both are recurrent aberrations in acute myeloid leukemia: Prevalence and prognostic value. Blood 2010, 116, 2122-2126. [CrossRef] [PubMed]

77. Kattih, B.; Shirvani, A.; Klement, P.; Garrido, A.M.; Gabdoulline, R.; Liebich, A.; Brandes, M.; Chaturvedi, A.; Seeger, T.; Thol, F.; et al. IDH1/2 mutations in acute myeloid leukemia patients and risk of coronary artery disease and cardiac dysfunction-a retrospective propensity score analysis. Leukemia 2021, 35, 1301-1316. [CrossRef] [PubMed]

78. Burd, A.; Levine, R.L.; Ruppert, A.S.; Mims, A.S.; Borate, U.; Stein, E.M.; Patel, P.; Baer, M.R.; Stock, W.; Deininger, M.; et al. Precision medicine treatment in acute myeloid leukemia using prospective genomic profiling: Feasibility and preliminary efficacy of the Beat AML Master Trial. Nat. Med. 2020, 26, 1852-1858. [CrossRef] [PubMed]

79. Burnett, A.K.; Milligan, D.; Prentice, A.G.; Goldstone, A.H.; McMullin, M.F.; Hills, R.K.; Wheatley, K. A comparison of low-dose cytarabine and hydroxyurea with or without all-trans retinoic acid for acute myeloid leukemia and high-risk myelodysplastic syndrome in patients not considered fit for intensive treatment. Cancer 2007, 109, 1114-1124. [CrossRef] [PubMed] 
80. Cortes, J.E.; Heidel, F.H.; Hellmann, A.; Fiedler, W.; Smith, B.D.; Robak, T.; Montesinos, P.; Pollyea, D.A.; DesJardins, P.; Ottmann, O.; et al. Randomized comparison of low dose cytarabine with or without glasdegib in patients with newly diagnosed acute myeloid leukemia or high-risk myelodysplastic syndrome. Leukemia 2019, 33, 379-389. [CrossRef]

81. Amadori, S.; Suciu, S.; Selleslag, D.; Aversa, F.; Gaidano, G.; Musso, M.; Annino, L.; Venditti, A.; Voso, M.T.; Mazzone, C.; et al. Gemtuzumab Ozogamicin Versus Best Supportive Care in Older Patients With Newly Diagnosed Acute Myeloid Leukemia Unsuitable for Intensive Chemotherapy: Results of the Randomized Phase III EORTC-GIMEMA AML-19 Trial. J. Clin. Oncol. 2016, 34, 972-979. [CrossRef]

82. Wei, A.H.; Jr, S.A.S.; Hou, J.-Z.; Fiedler, W.; Lin, T.L.; Walter, R.B.; Enjeti, A.; Tiong, I.S.; Savona, M.; Lee, S.; et al. Venetoclax Combined With Low-Dose Cytarabine for Previously Untreated Patients With Acute Myeloid Leukemia: Results From a Phase Ib/II Study. J. Clin. Oncol. 2019, 37, 1277-1284. [CrossRef] [PubMed]

83. Wei, A.H.; Montesinos, P.; Ivanov, V.; DiNardo, C.D.; Novak, J.; Laribi, K.; Kim, I.; Stevens, D.A.; Fiedler, W.; Pagoni, M.; et al. Venetoclax plus LDAC for newly diagnosed AML ineligible for intensive chemotherapy: A phase 3 randomized placebo-controlled trial. Blood 2020, 135, 2137-2145. [CrossRef]

84. Scappaticci, G.B.; Marini, B.L.; Nachar, V.R.; Uebel, J.R.; Vulaj, V.; Crouch, A.; Bixby, D.L.; Talpaz, M.; Perissinotti, A.J. Outcomes of previously untreated elderly patients with AML: A propensity score-matched comparison of clofarabine vs. FLAG. Ann. Hematol. 2018, 97, 573-584. [CrossRef]

85. Konopleva, M.; Pollyea, D.A.; Potluri, J.; Chyla, B.; Hogdal, L.; Busman, T.; McKeegan, E.; Salem, A.H.; Zhu, M.; Ricker, J.L.; et al. Efficacy and Biological Correlates of Response in a Phase II Study of Venetoclax Monotherapy in Patients with Acute Myelogenous Leukemia. Cancer Discov. 2016, 6, 1106-1117. [CrossRef]

86. Egan, P.C.; Reagan, J.L. The return of gemtuzumab ozogamicin: A humanized anti-CD33 monoclonal antibody-drug conjugate for the treatment of newly diagnosed acute myeloid leukemia. OncoTargets Ther. 2018, 11, 8265-8272. [CrossRef]

87. Bloomfield, C.D.; Lawrence, D.; Byrd, J.C.; Carroll, A.; Pettenati, M.J.; Tantravahi, R.; Patil, S.R.; Davey, F.R.; Berg, D.T.; Schiffer, C.A.; et al. Frequency of Prolonged Remission Duration after High-Dose Cytarabine Intensification in Acute Myeloid Leukemia Varies by Cytogenetic Subtype. Cancer Res. 1998, 58, 4173-4179. [PubMed]

88. Neubauer, A.; Maharry, K.; Mrózek, K.; Thiede, C.; Marcucci, G.; Paschka, P.; Mayer, R.J.; Larson, R.A.; Liu, E.T.; Bloomfield, C.D. Patients with Acute Myeloid Leukemia and RAS Mutations Benefit Most from Postremission High-Dose Cytarabine: A Cancer and Leukemia Group B Study. J. Clin. Oncol. 2008, 26, 4603-4609. [CrossRef]

89. Sperr, W.R.; Piribauer, M.; Wimazal, F.; Fonatsch, C.; Thalhammer-Scherrer, R.; Schwarzinger, I.; Geissler, K.; Knoebl, P.; Jäger, U.; Lechner, K.; et al. A Novel Effective and Safe Consolidation for Patients over 60 Years with Acute Myeloid Leukemia. Clin. Cancer Res. 2004, 10, 3965-3971. [CrossRef] [PubMed]

90. Fukushima, T.; Urasaki, Y.; Yamaguchi, M.; Ueda, M.; Morinaga, K.; Haba, T.; Sugiyama, T.; Nakao, S.; Origasa, H.; Umehara, H.; et al. A Randomized Comparison of Modified Intermediate-dose Ara-C versus High-dose Ara-C in Post-remission Therapy for Acute Myeloid Leukemia. Anticancer Res. 2012, 32, 643-647. [PubMed]

91. Jaramillo, S.; Benner, A.; Krauter, J.; Martin, H.; Kindler, T.; Bentz, M.; Salih, H.R.; Held, G.; Köhne, C.H.; Götze, K.; et al. Condensed versus standard schedule of high-dose cytarabine consolidation therapy with pegfilgrastim growth factor support in acute myeloid leukemia. Blood Cancer J. 2017, 7, e564. [CrossRef] [PubMed]

92. Muffly, L.; Pasquini, M.C.; Martens, M.; Brazauskas, R.; Zhu, X.; Adekola, K.; Aljurf, M.; Ballen, K.K.; Bajel, A.; Baron, F.; et al. Increasing use of allogeneic hematopoietic cell transplantation in patients aged 70 years and older in the United States. Blood 2017, 130, 1156-1164. [CrossRef]

93. McClune, B.L.; Weisdorf, D.J.; Pedersen, T.L.; Silva, G.T.d.; Tallman, M.S.; Sierra, J.; DiPersio, J.; Keating, A.; Gale, R.P.; George, B.; et al. Effect of Age on Outcome of Reduced-Intensity Hematopoietic Cell Transplantation for Older Patients With Acute Myeloid Leukemia in First Complete Remission or With Myelodysplastic Syndrome. J. Clin. Oncol. 2010, 28, 1878-1887. [CrossRef]

94. Lim, Z.; Brand, R.; Martino, R.; Biezen, A.v.; Finke, J.; Bacigalupo, A.; Beelen, D.; Devergie, A.; Alessandrino, E.; Willemze, R.; et al. Allogeneic Hematopoietic Stem-Cell Transplantation for Patients 50 Years or Older with Myelodysplastic Syndromes or Secondary Acute Myeloid Leukemia. J. Clin. Oncol. 2010, 28, 405-411. [CrossRef] [PubMed]

95. Modi, D.; Deol, A.; Kim, S.; Ayash, L.; Alavi, A.; Ventimiglia, M.; Bhutani, D.; Ratanatharathorn, V.; Uberti, J.P. Age does not adversely influence outcomes among patients older than 60 years who undergo allogeneic hematopoietic stem cell transplant for AML and myelodysplastic syndrome. Bone Marrow Transplant. 2017, 52, 1530-1536. [CrossRef] [PubMed]

96. Sorror, M.L.; Sandmaier, B.M.; Storer, B.E.; Franke, G.N.; Laport, G.G.; Chauncey, T.R.; Agura, E.; Maziarz, R.T.; Langston, A.; Hari, P.; et al. Long-term Outcomes among Older Patients Following Nonmyeloablative Conditioning and Allogeneic Hematopoietic Cell Transplantation for Advanced Hematologic Malignancies. JAMA 2011, 306, 1874-1883. [CrossRef] [PubMed]

97. Luger, S.M.; Ringdén, O.; Zhang, M.J.; Pérez, W.S.; Bishop, M.R.; Bornhauser, M.; Bredeson, C.N.; Cairo, M.S.; Copelan, E.A.; Gale, R.P.; et al. Similar outcomes using myeloablative vs. reduced-intensity allogeneic transplant preparative regimens for AML or MDS. Bone Marrow Transpl. 2012, 47, 203-211. [CrossRef]

98. Shimoni, A.; Shem-Tov, N.; Volchek, Y.; Danylesko, I.; Yerushalmi, R.; Nagler, A. Allo-SCT for AML and MDS with treosulfan compared with BU-based regimens: Reduced toxicity vs. reduced intensity. Bone Marrow Transplant. 2012, 47, 1274-1282. [CrossRef] [PubMed] 
99. Martino, R.; de Wreede, L.; Fiocco, M.; van Biezen, A.; von dem Borne, P.A.; Hamladji, R.M.; Volin, L.; Bornhäuser, M.; Robin, M.; Rocha, V.; et al. Comparison of conditioning regimens of various intensities for allogeneic hematopoietic SCT using HLA-identical sibling donors in AML and MDS with <10\% BM blasts: A report from EBMT. Bone Marrow Transpl. 2013, 48, 761-770. [CrossRef]

100. Devine, S.M.; Owzar, K.; Blum, W.; Mulkey, F.; Stone, R.M.; Hsu, J.W.; Champlin, R.E.; Chen, Y.-B.; Vij, R.; Slack, J.; et al. Phase II Study of Allogeneic Transplantation for Older Patients with Acute Myeloid Leukemia in First Complete Remission Using a Reduced-Intensity Conditioning Regimen: Results from Cancer and Leukemia Group B 100103 (Alliance for Clinical Trials in Oncology)/Blood and Marrow Transplant Clinical Trial Network 0502. J. Clin. Oncol. 2015, 33, 4167-4175. [CrossRef]

101. Rashidi, A.; DiPersio, J.F.; Westervelt, P.; Vij, R.; Schroeder, M.A.; Cashen, A.F.; Fehniger, T.A.; Romee, R. Comparison of Outcomes after Peripheral Blood Haploidentical versus Matched Unrelated Donor Allogeneic Hematopoietic Cell Transplantation in Patients with Acute Myeloid Leukemia: A Retrospective Single-Center Review. Biol. Blood Marrow Transplant. 2016, 22, $1696-1701$. [CrossRef]

102. Sandhu, K.S.; Brunstein, C.; DeFor, T.; Bejanyan, N.; Arora, M.; Warlick, E.; Weisdorf, D.; Ustun, C. Umbilical Cord Blood Transplantation Outcomes in Acute Myelogenous Leukemia/Myelodysplastic Syndrome Patients Aged $\geq 70$ Years. Biol. Blood Marrow Transplant. 2016, 22, 390-393. [CrossRef] [PubMed]

103. Versluis, J.; in 't Hout, F.E.M.; Devillier, R.; van Putten, W.L.J.; Manz, M.G.; Vekemans, M.C.; Legdeur, M.C.; Passweg, J.R.; Maertens, J.; Kuball, J.; et al. Comparative value of post-remission treatment in cytogenetically normal AML subclassified by NPM1 and FLT3-ITD allelic ratio. Leukemia 2017, 31, 26-33. [CrossRef] [PubMed]

104. Scott, B.L.; Pasquini, M.C.; Logan, B.R.; Wu, J.; Devine, S.M.; Porter, D.L.; Maziarz, R.T.; Warlick, E.D.; Fernandez, H.F.; Alyea, E.P.; et al. Myeloablative Versus Reduced-Intensity Hematopoietic Cell Transplantation for Acute Myeloid Leukemia and Myelodysplastic Syndromes. J. Clin. Oncol. 2017, 35, 1154-1161. [CrossRef] [PubMed]

105. Zeng, W.; Huang, L.; Meng, F.; Liu, Z.; Zhou, J.; Sun, H. Reduced-intensity and myeloablative conditioning allogeneic hematopoietic stem cell transplantation in patients with acute myeloid leukemia and myelodysplastic syndrome: A meta-analysis and systematic review. Int. J. Clin. Exp. Med. 2014, 7, 4357-4368. [PubMed]

106. Keating, A.; DaSilva, G.; Pérez, W.S.; Gupta, V.; Cutler, C.S.; Ballen, K.K.; Cairo, M.S.; Camitta, B.M.; Champlin, R.E.; Gajewski, J.L.; et al. Autologous blood cell transplantation versus HLA-identical sibling transplantation for acute myeloid leukemia in first complete remission: A registry study from the Center for International Blood and Marrow Transplantation Research. Haematologica 2013, 98, 185-192. [CrossRef]

107. Saraceni, F.; Labopin, M.; Gorin, N.-C.; Blaise, D.; Tabrizi, R.; Volin, L.; Cornelissen, J.; Cahn, J.-Y.; Chevallier, P.; Craddock, C.; et al. Matched and mismatched unrelated donor compared to autologous stem cell transplantation for acute myeloid leukemia in first complete remission: A retrospective, propensity score-weighted analysis from the ALWP of the EBMT. J. Hematol. Oncol. 2016, 9, 79. [CrossRef] [PubMed]

108. Saraceni, F.; Bruno, B.; Lemoli, R.M.; Meloni, G.; Arcese, W.; Falda, M.; Ciceri, F.; Alessandrino, E.P.; Specchia, G.; Scimè, R.; et al. Autologous stem cell transplantation is still a valid option in good- and intermediate-risk AML: A GITMO survey on 809 patients autografted in first complete remission. Bone Marrow Transplant. 2016, 52, 163-166. [CrossRef]

109. Mizutani, M.; Hara, M.; Fujita, H.; Aoki, J.; Kanamori, H.; Ohashi, K.; Usuki, K.; Fukuda, T.; Chou, T.; Tanaka, J.; et al. Comparable outcomes between autologous and allogeneic transplant for adult acute myeloid leukemia in first CR. Bone Marrow Transplant. 2016, 51, 645-653. [CrossRef]

110. Oriol, A.; Ribera, J.M.; Esteve, J.; Guardia, R.; Brunet, S.; Bueno, J.; Pedro, C.; Llorente, A.; Tormo, M.; Besalduch, J.; et al. Feasibility and results of autologous stem cell transplantation in de novo acute myeloid leukemia in patients over 60 years old. Results of the CETLAM AML-99 protocol. Haematologica 2004, 89, 791-800. [CrossRef]

111. Heini, A.D.; Berger, M.D.; Seipel, K.; Taleghani, B.M.; Baerlocher, G.M.; Leibundgut, K.; Banz, Y.; Novak, U.; Pabst, T. Consolidation with autologous stem cell transplantation in first remission is safe and effective in AML patients above 65 years. Leuk. Res. 2017, 53, 28-34. [CrossRef]

112. Huls, G.; Chitu, D.A.; Havelange, V.; Jongen-Lavrencic, M.; van de Loosdrecht, A.A.; Biemond, B.J.; Sinnige, H.; Hodossy, B.; Graux, C.; Kooy, R.v.M.; et al. Azacitidine maintenance after intensive chemotherapy improves DFS in older AML patients. Blood 2019, 133, 1457-1464. [CrossRef] [PubMed]

113. Oran, B.; de Lima, M.; Garcia-Manero, G.; Thall, P.F.; Lin, R.; Popat, U.; Alousi, A.M.; Hosing, C.; Giralt, S.; Rondon, G.; et al. A phase 3 randomized study of 5-azacitidine maintenance vs. observation after transplant in high-risk AML and MDS patients. Blood Adv. 2020, 4, 5580-5588. [CrossRef] [PubMed]

114. Wei, A.H.; Döhner, H.; Pocock, C.; Montesinos, P.; Afanasyev, B.; Dombret, H.; Ravandi, F.; Sayar, H.; Jang, J.-H.; Porkka, K.; et al. Oral Azacitidine Maintenance Therapy for Acute Myeloid Leukemia in First Remission. N. Engl. J. Med. 2020, 383, $2526-2537$. [CrossRef] [PubMed]

115. Reville, P.K.; Kantarjian, H.M.; Ravandi, F.; Jabbour, E.; DiNardo, C.D.; Daver, N.; Pemmaraju, N.; Ohanian, M.; Alvarado, Y.; Xiao, L.; et al. Nivolumab maintenance in high-risk acute myeloid leukemia patients: A single-arm, open-label, phase II study. Blood Cancer J. 2021, 11, 60. [CrossRef]

116. Schuurhuis, G.J.; Heuser, M.; Freeman, S.; Béné, M.-C.; Buccisano, F.; Cloos, J.; Grimwade, D.; Haferlach, T.; Hills, R.K.; Hourigan, C.S.; et al. Minimal/measurable residual disease in AML: A consensus document from the European LeukemiaNet MRD Working Party. Blood 2018, 131, 1275-1291. [CrossRef] 
117. Percival, M.-E.; Lai, C.; Estey, E.; Hourigan, C.S. Bone marrow evaluation for diagnosis and monitoring of acute myeloid leukemia. Blood Rev. 2017, 31, 185-192. [CrossRef] [PubMed]

118. Ivey, A.; Hills, R.K.; Simpson, M.A.; Jovanovic, J.V.; Gilkes, A.; Grech, A.; Patel, Y.; Bhudia, N.; Farah, H.; Mason, J.; et al. Assessment of Minimal Residual Disease in Standard-Risk AML. N. Engl. J. Med. 2016, 374, 422-433. [CrossRef]

119. Jongen-Lavrencic, M.; Grob, T.; Hanekamp, D.; Kavelaars, F.G.; al Hinai, A.; Zeilemaker, A.; Erpelinck-Verschueren, C.A.J.; Gradowska, P.L.; Meijer, R.; Cloos, J.; et al. Molecular Minimal Residual Disease in Acute Myeloid Leukemia. N. Engl. J. Med. 2018, 378, 1189-1199. [CrossRef] [PubMed]

120. Yoest, J.M.; Shirai, C.L.; Duncavage, E.J. Sequencing-Based Measurable Residual Disease Testing in Acute Myeloid Leukemia. Front. Cell Dev. Biol. 2020, 8, 249. [CrossRef] [PubMed]

121. Hourigan, C.S.; Dillon, L.W.; Gui, G.; Logan, B.R.; Fei, M.; Ghannam, J.; Li, Y.; Licon, A.; Alyea, E.P.; Bashey, A.; et al. Impact of Conditioning Intensity of Allogeneic Transplantation for Acute Myeloid Leukemia with Genomic Evidence of Residual Disease. J. Clin. Oncol. 2019, 38, 1273-1283. [CrossRef]

122. Patkar, N.; Kakirde, C.; Shaikh, A.F.; Salve, R.; Bhanshe, P.; Chatterjee, G.; Rajpal, S.; Joshi, S.; Chaudhary, S.; Kodgule, R.; et al Clinical impact of panel-based error-corrected next generation sequencing versus flow cytometry to detect measurable residual disease (MRD) in acute myeloid leukemia (AML). Leukemia 2021, 35, 1392-1404. [CrossRef] [PubMed]

123. Gökbuget, N.; Dombret, H.; Bonifacio, M.; Reichle, A.; Graux, C.; Faul, C.; Diedrich, H.; Topp, M.S.; Brüggemann, M.; Horst, H.-A.; et al. Blinatumomab for minimal residual disease in adults with B-cell precursor acute lymphoblastic leukemia. Blood 2018 131, 1522-1531. [CrossRef] [PubMed]

124. Morita, K.; Wang, F.; Jahn, K.; Hu, T.; Tanaka, T.; Sasaki, Y.; Kuipers, J.; Loghavi, S.; Wang, S.A.; Yan, Y.; et al. Clonal evolution of acute myeloid leukemia revealed by high-throughput single-cell genomics. Nat. Commun. 2020, 11, 5327. [CrossRef] [PubMed]

125. Hasserjian, R.P.; Steensma, D.P.; Graubert, T.A.; Ebert, B.L. Clonal hematopoiesis and measurable residual disease assessment in acute myeloid leukemia. Blood 2020, 135, 1729-1738. [CrossRef]

126. Tsai, C.-H.; Tang, J.-L.; Tien, F.-M.; Kuo, Y.-Y.; Wu, D.-C.; Lin, C.-C.; Tseng, M.-H.; Peng, Y.-L.; Hou, M.-F.; Chuang, Y.-K.; et al. Clinical implications of sequential MRD monitoring by NGS at 2 time points after chemotherapy in patients with AML. Blood Adv. 2021, 5, 2456-2466. [CrossRef]

127. Godwin, C.D.; Zhou, Y.; Othus, M.; Asmuth, M.M.; Shaw, C.M.; Gardner, K.M.; Wood, B.L.; Walter, R.B.; Estey, E.H. Acute myeloid leukemia measurable residual disease detection by flow cytometry in peripheral blood vs. bone marrow. Blood 2021, 137, 569-572. [CrossRef]

128. LeBlanc, T.W.; El-Jawahri, A. When and why should patients with hematologic malignancies see a palliative care specialist? Hematology 2015, 2015, 471-478. [CrossRef]

129. El-Jawahri, A.; Nelson, A.M.; Gray, T.F.; Lee, S.J.; LeBlanc, T.W. Palliative and End-of-Life Care for Patients With Hematologic Malignancies. J. Clin. Oncol. 2020, 38, 944-953. [CrossRef] [PubMed]

130. LeBlanc, T.W.; Ritchie, C.S.; Friedman, F.; Bull, J.; Kutner, J.S.; Johnson, K.S.; Kamal, A.H.; Aslakson, R.A.; Ast, K.; Elk, R.; et al Adherence to Measuring What Matters Items When Caring for Patients with Hematologic Malignancies versus Solid Tumors. J. Pain Symptom Manag. 2016, 52, 775-782. [CrossRef]

131. Rao, V.B.; Belanger, E.; Egan, P.C.; LeBlanc, T.W.; Olszewski, A.J. Early Palliative Care Services and End-of-Life Care in Medicare Beneficiaries with Hematologic Malignancies: A Population-Based Retrospective Cohort Study. J. Palliat. Med. 2021, 24, 63-70. [CrossRef]

132. El-Jawahri, A.; LeBlanc, T.W.; Kavanaugh, A.; Webb, J.A.; Jackson, V.A.; Campbell, T.C.; O'Connor, N.; Luger, S.M.; Gafford, E.; Gustin, J.; et al. Effectiveness of Integrated Palliative and Oncology Care for Patients with Acute Myeloid Leukemia: A Randomized Clinical Trial. JAMA Oncol. 2021, 7, 238-245. [CrossRef] [PubMed]

133. Uy, G.L.; Yin, J.; Klepin, H.D.; Dinner, S.; Jaslowski, A.J.; Strickland, S.A.; Liesveld, J.L.; Byrd, J.C.; Stone, R.M. Alliance A041701 -A Randomized Phase 2/3 Study of Conventional Chemotherapy + / - Uproleselan (GMI-1271) in Older Adults with Acute Myeloid Leukemia (AML) Receiving Intensive Induction Chemotherapy. Blood 2019, 134, 1366. [CrossRef]

134. DeAngelo, D.J.; Erba, H.P.; Jonas, B.A.; O’Dwyer, M.; Marlton, P.; Huls, G.A.; Liesveld, J.; Cooper, B.W.; Bhatnagar, B.; Armstrong, M.; et al. A phase III trial to evaluate the efficacy of uproleselan (GMI-1271) with chemotherapy in patients with relapsed/refractory acute myeloid leukemia. J. Clin. Oncol. 2019, 37, TPS7066. [CrossRef]

135. Cluzeau, T.; Sebert, M.; Rahmé, R.; Cuzzubbo, S.; Lehmann-Che, J.; Madelaine, I.; Peterlin, P.; Bève, B.; Attalah, H.; Chermat, F.; et al. Eprenetapopt Plus Azacitidine in TP53-Mutated Myelodysplastic Syndromes and Acute Myeloid Leukemia: A Phase II Study by the Groupe Francophone des Myélodysplasies (GFM). J. Clin. Oncol. 2021, 39, 1575-1583. [CrossRef] [PubMed]

136. Sallman, D.A.; DeZern, A.E.; Garcia-Manero, G.; Steensma, D.P.; Roboz, G.J.; Sekeres, M.A.; Cluzeau, T.; Sweet, K.L.; McLemore, A.; McGraw, K.L.; et al. Eprenetapopt (APR-246) and Azacitidine in TP53-Mutant Myelodysplastic Syndromes. J. Clin. Oncol. 2021, 39, 1584-1594. [CrossRef]

137. Zayac, A.; Egan, P.C.; Ollila, T.A.; Olszewski, A.J.; Barth, P.; Quesenberry, M.I.; Butera, J.; Fast, L.D.; Niroula, R.; Quesenberry, P.J.; et al. BrUOG 345: Fractionated Gemtuzumab Ozogamicin Followed by Non-Engraftment Donor Leukocyte Infusions for Relapsed/Refractory Acute Myeloid Leukemia. Blood 2019, 134, 4460. [CrossRef]

138. Cummins, K.D.; Gill, S. Chimeric antigen receptor T-cell therapy for acute myeloid leukemia: How close to reality? Haematologica 2019, 104, 1302-1308. [CrossRef] 
139. Center for International Blood and Marrow Transplant Research; National Marrow Donor Program; St. Baldrick's Foundation. Study of Anti-CD33 Chimeric Antigen Receptor-Expressing T Cells (CD33CART) in Children and Young Adults with Relapsed/Refractory Acute Myeloid Leukemia; National Library of Medicine: Bethesda, MD, USA, 2020.

140. He, X.; Feng, Z.; Ma, J.; Ling, S.; Cao, Y.; Gurung, B.; Wu, Y.; Katona, B.W.; O’Dwyer, K.P.; Siegel, D.L.; et al. Bispecific and split CAR T cells targeting CD13 and TIM3 eradicate acute myeloid leukemia. Blood 2020, 135, 713-723. [CrossRef]

141. Wermke, M.; Kraus, S.; Ehninger, A.; Bargou, R.C.; Goebeler, M.-E.; Middeke, J.M.; Kreissig, C.; von Bonin, M.; Koedam, J.; Pehl, M.; et al. Proof of concept for a rapidly switchable universal CAR-T platform with UniCAR-T-CD123 in relapsed/refractory AML. Blood 2021, 137, 3145-3148. [CrossRef] [PubMed]

142. Sauer, T.; Parikh, K.; Sharma, S.; Omer, B.; Sedloev, D.N.; Chen, Q.; Angenendt, L.; Schliemann, C.; Schmitt, M.; Müller-Tidow, C.; et al. CD70-specific CAR T-cells have potent activity against Acute Myeloid Leukemia (AML) without HSC toxicity. Blood 2021, 138, 318-330. [CrossRef] [PubMed]

143. Chu, S.Y.; Pong, E.; Chen, H.; Phung, S.; Chan, E.W.; Endo, N.A.; Rashid, R.; Bonzon, C.; Leung, I.W.L.; Muchhal, U.S.; et al. Immunotherapy with Long-Lived Anti-CD123 $\times$ Anti-CD3 Bispecific Antibodies Stimulates Potent T Cell-Mediated Killing of Human AML Cell Lines and of CD123+ Cells in Monkeys: A Potential Therapy for Acute Myelogenous Leukemia. Blood 2014, 124, 2316. [CrossRef]

144. Guy, D.G.; Uy, G.L. Bispecific Antibodies for the Treatment of Acute Myeloid Leukemia. Curr. Hematol. Malig. Rep. 2018, 13, 417-425. [CrossRef]

145. Clark, M.C.; Stein, A. CD33 directed bispecific antibodies in acute myeloid leukemia. Best Pract. Res. Clin. Haematol. 2020, 33, 101224. [CrossRef] [PubMed]

146. Hoseini, S.S.; Cheung, N.K. Acute myeloid leukemia targets for bispecific antibodies. Blood Cancer J. 2017, 7, e522. [CrossRef]

147. Yeung, Y.A.; Krishnamoorthy, V.; Dettling, D.; Sommer, C.; Poulsen, K.; Ni, I.; Pham, A.; Chen, W.; Liao-Chan, S.; Lindquist, K.; et al. An Optimized Full-Length FLT3/CD3 Bispecific Antibody Demonstrates Potent Anti-leukemia Activity and Reversible Hematological Toxicity. Mol. Ther. 2020, 28, 889-900. [CrossRef] [PubMed] 